\title{
Balanced primary sex ratios and resilience to climate change in a major marine turtle population
}

3

\section{Running title: Green turtle primary sex ratios}

Patrício, A.R. ${ }^{1}{ }^{2}$, Marques, A. ${ }^{3}$, Barbosa, C. ${ }^{4}$ Broderick, A.C. ${ }^{1}$, Godley, B.J. ${ }^{1}$, Hawkes, L.A. ${ }^{1}$, Rebelo, R. ${ }^{2}$, Regalla, A. ${ }^{4}$ and Catry, P. ${ }^{2}$

${ }^{1}$ Centre for Ecology and Conservation, University of Exeter, TR10 9FE, Penryn, UK

${ }^{2}$ MARE - Marine and Environmental Sciences Centre, ISPA - Instituto Universitário, 1140041, Lisbon, Portugal

${ }^{3}$ Centre for Ecology, Evolution and Environmental Changes (CE3C), Faculdade de Ciências, Universidade de Lisboa, Bloco C2, Campo Grande, 1749-016 Lisboa, Portugal

${ }^{4}$ Institute of Biodiversity and Protected Areas of Guinea-Bissau (IBAP), CP - 70, Bissau, Guinea Bissau

Corresponding author: Rita Patrício. R.Patricio@exeter.ac.uk. 07747868144. TR10 9FE, UK

\begin{abstract}
Global climate change is expected to have major impacts on biodiversity. Marine turtles have temperature-dependent sex determination, and many populations produce highly femalebiased offspring sex ratios, a skew likely to increase further with global warming. We looked at one of the world's largest green turtle rookeries, in West Africa, to assess the population's primary sex ratio and resilience to climate change. In 2013 and 2014, we deployed dataloggers recording nest $(n=101)$ and sand $(n=30)$ temperatures, and identified hatchling sex $(n=131)$ by histological examination of gonads. A logistic curve was fitted to the data, to allow predictions of sex ratio across habitats and through the nesting season. The population-specific pivotal temperature was $29.4^{\circ} \mathrm{C}$, and both sexes were produced within incubation temperatures from $27.6^{\circ} \mathrm{C}$ to $31.4^{\circ} \mathrm{C}$ : transitional range of temperatures (TRT). Primary sex ratio changed from male to female dominated across relatively small temporal and spatial scales, but was overall balanced. We estimated an exceptionally high male hatchling production of $47.7 \%(95 \% \mathrm{Cl}$ : $36.7-58.3 \%)$ and $44.5 \%(95 \% \mathrm{Cl}$ : $33.8-55.4 \%)$ in 2013 and 2014, respectively. Both the temporal and spatial variation in incubation conditions, and the wide range of the TRT, suggest resilience and potential for adaptation to climate change, if the present nesting habitat remains unchanged. These findings underline the importance of assessing site-specific parameters to understand populations' response to climate change, particularly with regard to identifying rookeries with high male hatchling production that may be key for the future conservation of sea turtles, under projected global warming scenarios.
\end{abstract}

Key-words: sex ratio; climate change; green turtle; pivotal temperature; transitional range of temperatures; thermosensitive period

To be cited as:

Patrício A.R., Marques A., Barbosa C., Broderick A.C., Godley B.J., Hawkes L.A., Rebelo R., Regalla A., Catry P. 2017. Balanced primary sex ratios and resilience to climate change in a major sea turtle population. Marine Ecology Progress Series 577: 189-203. DOI:10.3354/meps12242 


\section{Introduction}

Sex ratio is an important parameter to assess population viability and resilience (Melbourne and Hastings, 2008; Mitchell et al. 2010). Balanced sex ratios, where males and females are approximately equal in numbers, seem to be the norm among species with genotypic sex determination (GSD) where frequency-dependent selection on the primary sex ratio is strong (Fisher 1930). In species with environmental-dependent sex determination (ESD) however, deviations from this equilibrium are widely observed (Bull, 1983). Temperature-dependent sex determination (TSD) is the most common mechanism of ESD, in which offspring sex is determined by the incubation temperatures experienced during the thermosensitive period (TSP), corresponding approximately to the middle third of embryogenesis (Bull, 1983). This is the mechanism of sex differentiation among crocodilians (Lang and Andrews, 1994), sphenodontians (Mitchell et al. 2010), some lizards (Viets et al., 1994), and most turtle species (Mrosovsky \& Yntema 1980).

Among marine turtles, clutches demonstrate a thermal tolerance of $23^{\circ} \mathrm{C}$ to $35^{\circ} \mathrm{C}$ during incubation (Ackerman, 1997). During the TSP, higher incubation temperatures produce female offspring, whereas lower incubation temperatures produce males (Mrosovsky and Yntema, 1980). Between these extremes, there is a transitional range of temperatures (TRT) at which both sexes can be produced (Mrosovsky and Yntema, 1980). The constant temperature resulting in a 1:1 sex ratio is known as the pivotal temperature, and it has been shown under laboratory conditions to be approximately $29 \stackrel{\circ}{\mathrm{C}}$ for most sea turtle species (Ackerman 1997; Hawkes et al. 2009; Witt et al. 2010). Because under natural conditions the incubation temperatures fluctuate, typically associated with rainstorm events (Godfrey et al., 1996; Houghton et al., 2007; Lolavar and Wyneken, 2015; Matsuzawa et al., 2002) or diel temperature variation (Georges, 2013), the equivalent of the pivotal temperature is given as the mean of the temperatures experienced during the middle third of incubation leading to a balanced sex ratio (Mrosovsky and Pieau, 1991). Relatively few field studies have derived 'pivotal temperatures' (but see Broderick et al., 2000; Godley et al. 2002). 
Because extreme temperatures could lead to the production of hatchlings of a single sex, marine turtles have been considered vulnerable to rapid climate and habitat change, as these may modify the thermal environment of their nests, skewing primary sex ratios (Hawkes et al. 2009; Mitchell \& Janzen 2010; Poloczanska et al. 2010; Witt et al. 2010). Only one study thus far has described male-biased primary sex ratios (Esteban et al., 2016). The majority of studies at sea turtle rookeries have estimated female-biased hatchling sex ratios, likely to worsen with future climate change (Hawkes et al. 2007; Fuentes et al. 2009; Fuentes et al. 2010a; Katselidis et al. 2012; Reneker \& Kamel 2016), and beachfront deforestation (Kamel \& Mrosovsky 2006; Kamel 2013). Feminising temperatures prolonged through generations could potentially lead to adaptive responses; by phenotypic plasticity and/or microevolutionary shifts in threshold temperatures, or otherwise lead to population extinction (Hulin et al., 2009; Mitchell and Janzen, 2010). Although sea turtles have endured pronounced past climate variations (Poloczanska et al. 2010), it is uncertain whether they can adapt to the predicted future scenarios of change. Additionally, despite the fact that many major populations are recovering from historical exploitation following conservation efforts (McClenachan et al. 2006; Weber et al. 2014), climate change impacts may act synergistically with other existing threats to arrest population growth (Brook et al., 2008). Populations of marine turtles that nest across a wider range of thermal conditions should produce a broader variation in offspring sex ratio and thus should be more resilient to climate change and have higher chances of adaptation (Abella Perez et al., 2016).

Despite the increase in research on sea turtle primary sex ratios, and on the impacts of climate change in this trait (Rees et al., 2016), there are significant gaps in information at both regional and species levels (Fuller et al., 2013; Hawkes et al., 2009). The majority of research has been focused on loggerhead turtles (Caretta caretta), followed by green turtles (Chelonia mydas), with less data on the remaining species (Hawkes et al., 2009). Geographically, most studies have been conducted on Mediterranean (Broderick et al. 2000; Casale et al. 2000; Godley et al. 2001b; Kaska et al. 2006; Zbinden et al. 2007; Katselidis et 
al. 2012; Fuller et al. 2013; Candan \& Kolankaya 2016), West Atlantic (Marcovaldi et al. 1997; Godfrey \& Mrosovsky 2006; Hawkes et al. 2007; Houghton et al. 2007; Mrosovsky et al. 2009; LeBlanc et al. 2012; Patino-Martinez et al. 2012; Kamel 2013; Braun McNeill et al. 2016; Laloë et al. 2016; Reneker \& Kamel 2016) and Australian (Booth \& Freeman 2006; Fuentes et al. 2009; Fuentes et al. 2010a) turtle populations. Very limited information is yet available for most of the Pacific (King et al. 2013; Kobayashi et al. 2017), the Indian (Esteban et al., 2016), and the Eastern Atlantic Oceans (Abella Perez et al., 2016).

Guinea-Bissau, West Africa, hosts one of world's largest green turtle nesting populations (Catry et al. 2002; Catry et al. 2009), and is the main nesting site within the green turtle Southern Atlantic distinct population segment (Seminoff et al. 2015). A study using dead hatchlings to predict primary sex ratios estimated $45 \%$ and $15 \%$ of male offspring for early and late-season clutches respectively, these differences likely being explained by rainfall (Rebelo et al., 2011). Although their study importantly detected a temporal variation in male production, it did not encompass the duration of the nesting season, nor the diversity of nesting habitats. We aim to contribute to the regional knowledge on green turtle primary sex ratios, and set out to 1) estimate population-specific pivotal temperature and TRT, 2) determine the range of temporal and spatial incubation conditions available at Poilão Island throughout the nesting season, and 3) predict the current primary sex ratio.

\section{Materials and methods}

\section{Study site}

In Guinea-Bissau, green turtles nest throughout the Bijagós Archipelago, with the vast majority of the clutches laid at Poilão $\left(10^{\circ} 52^{\prime} \mathrm{N}, 15^{\circ} 43^{\prime} \mathrm{W}\right.$, Catry et al. 2002; Catry et al. 2009), the smallest and southernmost island within the João Vieira and Poilão Marine National Park (JVPMNP, Fig. 1a). Poilão has a total area of 43 hectares, is covered by undisturbed tropical forest, and sandy beaches extend for $2 \mathrm{~km}$ of the ca. $4 \mathrm{~km}$ coastline (Fig. 1b). The nesting season (mid-June to mid-December, Catry et al. 2002), largely 
coincides with the rainy season (May to November, peaking in August and September), although sporadic nesting occurs year-round.

\section{Temporal nesting distribution}

To assess the number of adult female emergences we conducted systematic track counts from 7 August to 21 November in 2013 (106 days), and from 10 August to 28 November in 2014 (111 days). Weather conditions prevented us from surveying the beach on seven (6.6\% of the period covered) and three (2.7\% of the period covered) days, in 2013 and 2014 , respectively. We used linear interpolation to account for missing data (Godley et al. 2001c). Our surveys did not cover the beginning and end of the nesting season, so previous surveys (2000 and 2007, Catry et al. 2009), were used to reconstruct mean nesting frequency distribution at Poilão, at the start and end of the season. Following Metcalfe et al. (2015) we pooled daily counts into half-month bins, and divided each half-month value by the maximum half-month value (i.e. bin with the highest track count), to obtain a distribution of the mean proportion of the season's maximum. We did not divide each bin by the total sum of the track counts because, as mentioned above, not all of each season's emergences were recorded. We further reconstructed one half-bin at the beginning of the season, starting in 15 June, by attributing a value of $50 \%$ of the subsequent half-month bin, to cover the whole nesting season (Metcalfe et al., 2015).

\section{Spatial nesting distribution}

The nesting area was divided in four beach sections, from West to East (1 - 4, Fig.1b). A smaller beach in the east (5, Fig.1b) was not monitored due to difficult access, nests here represent $<5 \%$ of the overall numbers (Castro Barbosa pers. obs.). Within each section we classified the distribution of nests according to three habitats: 'forest', 'forest border' and 'open sand'. The 'forest' habitat encompassed the nesting area surrounded by vegetation and was shaded, the 'forest border' comprised a band within $0-1 \mathrm{~m}$ of the vegetation and experienced partial shade, and the 'open sand' corresponded to the area from $>1 \mathrm{~m}$ of the 
vegetation to the high tide line, exposed to the sun throughout all or most of the day (see

162 Fig. S1).

163 Due to the exceptionally high nesting density at Poilão, females typically disturb each other's nests (Catry et al., 2009), making it impractical to locate these, even on the subsequent morning. Thus, to determine nest distribution across habitats we monitored turtle nesting activity at night, for three nights in 2013 ( $n=407$ nests identified) and six nights in 2014 ( $n=$ 1,152 nests identified), and determined the habitat and beach section for all 1,559 nests. During these focused assessments we surveyed all four beach sections $(2 \mathrm{~km})$, at high tide (see Catry et al. 2002), as fast as possible (typically $<1$ hour), to ensure that most females were detected. Only females that were laying, covering or camouflaging nests were counted, as otherwise turtles could still change their location or abandon nesting activity. We used chi-square statistics to test if the distribution of nests among beach sections, and among habitats within each beach section, was independent of survey date, within and between years.

\section{Nest and sand temperatures}

From September to November 2013, and August to October 2014, we recorded hourly nest temperatures with Tinytag-TGP-4017 dataloggers (Gemini Data Loggers, Chichester, UK, \pm $0.3^{\circ} \mathrm{C}$ accuracy, $0.1^{\circ} \mathrm{C}$ resolution). We placed dataloggers in the centre of each clutch ( $n=101$ nests; 46 and 55 in 2013 and 2014, respectively), after ca. 50 eggs were laid, and we encircled each nest with three wooden poles, to help prevent destruction by other nesting females. For a subset of nests ( $n=30 ; 16$ and 14 for 2013 and 2014 respectively), control dataloggers were deployed 1 metre from the clutch, at a mean mid-clutch depth of $\sim 70 \mathrm{~cm}$ (local data, unpublished), to estimate the difference in sand temperature associated with metabolic heat produced by the eggs (Broderick et al., 2001a). Nest and control loggers were distributed across the four beach sections (section 1: $n=19$ nests; 5 control sites, section 2 : $n=25 ; 7$, section $3: n=26 ; 8$, section $4: n=31 ; 10)$, and the three habitats identified ('open sand': $n=64$ nests; 11 control sites, 'forest border': $n=21 ; 9$, 'forest': $n=16 ; 10$ ). All 
dataloggers were calibrated before and after each field season in a constant temperature room (24 hours at $28^{\circ} \mathrm{C}$ ) and used only if accuracy was $\leq 0.3^{\circ} \mathrm{C}$. Data were used to calculate mean temperatures during the middle third of incubation $\left(I P_{\text {mid }}\right)$, with the incubation period (IP) ending at hatching (identified as a peak in temperature followed by a decrease until emergence, Matsuzawa et al. 2002). We discarded the initial four hours of temperature records, to enable data loggers to equilibrate with the surrounding sand (Broderick et al., 2001a).

For each nest we recorded beach section and habitat. At nest excavation we further recorded: nest chamber depth (after all nests contents were removed), clutch size (from a count of hatched and unhatched eggs), hatching success ( $H \%=n$ hatched egg shells $/$ clutch size $)$, and emergence success $(\mathrm{E} \%=$ (n egg shells - $\mathrm{n}$ dead and live hatchlings found inside nest chamber)/clutch size). A control data logger at the 'forest border' was left to measure sand temperature from March 2013 to March 2015, enabling comparisons with local air temperature obtained from the National Climatic Data Centre (http://cdo.ncdc.noaa.gov/CDO/cdo). We estimated IP $P_{\text {mid }}$ mean incubation temperatures for nests laid from 15 June to 15 December (2013 and 2014) by calculating an 18-day moving average of sand temperature at each habitat (18 days corresponding to the mean duration of $\mathrm{IP}_{\text {mid; }}$ this study), and added mean metabolic heating $\left(0.5^{\circ} \mathrm{C}\right.$ mean value for this study). Sand temperature was regressed against air temperature in Bissau to reconstruct sand temperatures for periods of missing data (i.e. when no dataloggers recorded sand temperature).

\section{Sex ratio estimations}

In 2013 we deployed wire traps (50 cm diameter x $30 \mathrm{~cm}$ height, wire mesh $1 \mathrm{~cm}^{2}$ ) above 27 nests, from day 45 of incubation, checking them daily for emergent hatchlings. A random sample of four to five hatchlings per nest (total 131 hatchlings) were sacrificed, following procedures in Stocker (2005), for sex identification. Straight-carapace-length (SCL) of hatchlings was measured to $0.01 \mathrm{~cm}$ with a digital caliper. Sampling and handling protocols 
were approved by the research ethics committee of the University of Exeter, and the government of the Republic of Guinea-Bissau. Kidney-gonad complexes were extracted through dissection and stored in $96 \%$ ethanol. In an effort to compensate for this action, across the two field seasons, we saved over 2,000 hatchlings from stranding on the intertidal rocks, where they generally die from exposure to sunshine and avian predators.

Histological examination of gonads was conducted at the University of Lisbon. Cross sections of the kidney-gonad complex were kept for 16 hours in a 50:50 mix of resin (Kulzer, Technovit 7100 system) and $96 \%$ ethanol, followed by 24 hours in 100\% resin, and a further 24 hours in a mix of resin and hardener (Kulzer, Technovit® 7100 hardener, $1 \mathrm{ml}$ for each 15 $\mathrm{ml}$ of resin). The cross sections were then sectioned further into $3 \mathrm{~mm}$-width slices using a Leica RM 2155 microtome, allowed to dry for 24 hours, stained with toluidine blue for one minute and mounted with NeoMount glue. Photographs of each section were obtained with a Leica DFC 290, using software Irfanview v.4.27 (Skiljan, 2012). Identification of gonad structures and paramesonephric ducts followed criteria described in Miller \& Limpus (2003). Sex assignment was independently conducted by two researchers (AM and RR).

Consistency in sex identification was 95\% (compared for 131 hatchlings); for mismatched assignments $(n=7)$ observers conferred until reaching agreement.

\section{Data analysis}

Generalised Linear Models (GLM) with Gaussian error structure and identity link function were used to test for the effects of beach, habitat, nest depth and clutch size (independent variables) on i) $\mathrm{IP}_{\text {mid }}$ mean incubation temperature (response variable); and ii) hatching and emergence successes (response variables).

Most studies consider the IP $\mathrm{P}_{\text {mid }}$ as the thermosensitive period, however, as gonad differentiation depends on embryonic development rather than incubation duration, the thermosensitive period (TSP) in nests with fluctuating temperatures may differ from the $I P_{\text {mid }}$ (Girondot and Kaska, 2014). We thus used R package embryogrowth v.6.4 (see Girondot and Kaska, 2014 for detailed methods), which accounts for the stages of embryonic 
development in response to temperature, to estimate the beginning, end, and mean incubation temperatures of the TSP, for each nest with sexed hatchlings, using gastrula size for C. mydas from Kaska \& Downie (1999), mean hatchling size (SCL) from our data, and other parameters following Girondot \& Kaska (2014). GLMs with binomial errors and logit function were fitted to our data of sex ratio (response variable) against the following independent variables: i) IP mid mean incubation temperature, ii) TSP mean incubation temperature, and iii) IP (to hatching). We assessed goodness-of-fit of GLMs through pvalues and deviance. The best-fit logistic response function with $95 \%$ confidence intervals (CI) and reconstructed $\mathrm{IP}_{\text {mid }}$ mean incubation temperatures, across habitat and nesting season, were used to estimate primary sex ratios in 2013 and 2014. All statistical tests and models were conducted using R v.3.2.5 (R Development Core Team 2008). Estimates are presented as mean $\pm \mathrm{SD}$, unless stated otherwise.

\section{Results}

\section{Nesting distribution}

During our daily surveys we counted 48,696 green turtle tracks in 2013 , and 83,304 in 2014, from early August to late November, corresponding to 24,348 and 41,652 female emergences, respectively (each emergence corresponding to an ascending and a descending track). Following Catry et al (2009), we multiplied the number of emergences by 1.05 , to account for the period of the nesting season that we did not monitor, and by 0.813 to adjust for nesting success (Catry et al. 2009). We estimate that in total 20,785 clutches (95\% Cl: $18,049-22,855)$ were laid in 2013 and 35,556 clutches $(95 \% \mathrm{Cl}: 30,877-39,099)$ were laid in 2014. Peak nesting activity in both years was from August to September, coinciding with heavier precipitation (Fig. 2a, b, e, f).

The largest proportion $(34.7 \pm 1.4 \%)$ of tracks were found in section 1 , followed by $24.9 \pm$ $0.2 \%$ in section 4 and $20.4 \pm 0.6 \%$, and $20.0 \pm 1.0 \%$ in sections 3 and 2 respectively. There was no difference in nesting distribution among beach sections $\left(\chi^{2}(3)=0.14, P=0.98\right)$ or habitats ('forest', 'forest border', 'open sand'; Table S1) within and between study years. We 
273 thus calculated the mean nesting distribution among habitats; within each beach section

274 (Fig.1b), and overall. Most of the clutches were laid in the 'open sand' $64.2 \pm 7.9 \%$, followed by the 'forest' $22.1 \pm 7.8 \%$, and the 'forest border' $13.7 \pm 5.1 \%$.

\section{Incubation temperatures}

278 Clutch size $\left(120.3 \pm 30.2, n=98, F_{1,95}=0.7, P=0.4\right)$ and bottom nest depth $(0.8 m \pm 0.2, n=98$,

$\left.279 F_{1,97}=0.8, P=0.4\right)$ were poor predictors of $I_{\text {mid }}$ mean incubation temperatures. However, 280 there were significant differences among nesting habitats $\left(F_{2,89}=27.1, P<0.01\right)$, with $I P_{\text {mid }}$ mean incubation temperatures increasing from the 'forest' $\left(28.3^{\circ} \mathrm{C} \pm 0.7\right.$; range: $27.5-29.0$ $\left.{ }^{\circ} \mathrm{C}, \mathrm{n}=16\right)$, to the 'forest border' $\left(29.7^{\circ} \mathrm{C} \pm 0.7\right.$; range: $\left.28.5-30.3^{\circ} \mathrm{C}, \mathrm{n}=21\right)$, and to the 'open sand' (30.6 ${ }^{\circ} \mathrm{C} \pm 0.8$; range: $\left.29.2-32.3^{\circ} \mathrm{C}, \mathrm{n}=64\right)$. Additionally, there were significant differences in $I P_{\text {mid }}$ mean incubation temperatures among beach sections $\left(F_{3,89}=27.1\right.$, $P<0.01$ ), and within habitats among beach sections (i.e. interaction of beach section and habitat: $\left.F_{6,89}=27.1, P=0.04\right)$. A post hoc Tukey HSD test indicated that the $\mathrm{IP}_{\text {mid }}$ mean incubation temperature at the 'open sand' habitat in eastern beach sections ( 3 and 4 in Fig. $1 b)$ was significantly warmer $\left(31.1^{\circ} \mathrm{C} \pm 0.6\right.$; range: $29.7-32.8^{\circ} \mathrm{C}, \mathrm{n}=38$, Fig. S2, Table S2) than in the western sections (1 and 2 in Fig. $1 b$ ). In addition, $I P_{\text {mid }}$ mean incubation temperatures of the 'open sand' nests located in the western sections ( $29.9{ }^{\circ} \mathrm{C} \pm 0.6$; range: $\left.29.2-31.1^{\circ} \mathrm{C}, \mathrm{n}=25\right)$ were not significantly different from the nests located in the 'forest border' $(P=0.45)$. Thus, we assumed that clutches laid at the 'open sand' in the western beach sections' experienced the same incubation temperatures predicted for the 'forest border' habitat.

To estimate mean incubation temperatures at each habitat throughout both nesting seasons, we added mean daily differences in sand temperature, at the 'open sand' (1.0 ${ }^{\circ} \mathrm{C}$, Fig. S3a, b) and at the 'forest' habitat $\left(-1.5^{\circ} \mathrm{C}\right.$, Fig. S3a, b), to the 18-day moving averages of the reference sand temperatures ('forest border'). Sand temperatures were highly correlated among habitats ('open sand' vs. 'forest border' $r^{2}=0.96$, and 'forest border' vs. 'forest' $r^{2}=0.94$, Fig. S3c). We were unable to get sand temperatures for December 2013 and for 
July 2014, so we reconstructed these with air temperature using the equation $T$ sand $=$ 0.94 Tair_Bissau $+3.04\left(T=\right.$ temperature ${ }^{\circ} \mathrm{C}, \mathrm{F}_{1,37}=54.53, P<0.0001, \mathrm{r}^{2}=0.60$, Fig. S4).

Finally, we added $0.5^{\circ} \mathrm{C}$ of mean metabolic heating, estimated for the $\mathrm{IP}_{\text {mid }}\left(0.5^{\circ} \mathrm{C} \pm 0.4\right.$, range: $-0.4-1.2 \stackrel{\circ}{\circ}, n=20$ ). There were no significant differences among habitats in metabolic heating $\left(F_{12,17}=1.7, P=0.22\right)$. Lower $I P_{\text {mid }}$ incubation temperatures were predicted for nests laid in July and August, with higher temperatures expected for clutches laid in September and October (Fig. 2c, d).

\section{Incubation period (IP)}

We were able to estimate the IP (to hatching) of 88 nests, ranging from 40 to 70 days, with a mean of $53.5 \pm 5.0$ days $(n=88)$. For the remaining 13 nests we estimated the IP by subtracting to the emergence date the mean length of the period between hatching and emergence, which was $5.0 \pm 1.4$ days. The IP was inversely correlated with mean incubation temperature $\left(I P=-3.4644\right.$ * mean incubation temperature $\left.+156.92, r^{2}=0.87, P<0.0001\right)$. Consequently, mean IP decreased from the 'forest' habitat ( $60.2 \pm 5.1$ days, $n=13)$, to the 'forest border' ( $55.5 \pm 3.9$ days, $n=16)$, and to the 'open sand' ( $51.3 \pm 3.5$ days, $n=59)$.

\section{Hatching and emergence successes}

Hatching success ranged from 0 to $100 \%$, with a mean of $65.4 \pm 33.9 \%$, and we found no significant relationship with either clutch size $\left(F_{1,93}=2.6, P=0.113\right)$, nest depth $\left(F_{1,92}=0.2\right.$, $P=0.647)$, beach section $\left(F_{3,94}=1.9, P=0.126\right)$, or habitat $\left(F_{2,95}=2.2, P=0.119\right)$. The emergence success was also independent of clutch size $\left(F_{1,93}=3.6, P=0.062\right)$, nest depth $\left(F_{1,92}=0.3, P=0.592\right)$, and beach section $\left(F_{3,94}=3.1, P=0.052\right)$, but dependent of nesting habitat $\left(F_{2,95}=3.7, P=0.028\right)$. Emergence success decreased from the 'open sand' (66.1 \pm $30.8 \%$, range: $0.0-100 \%, n=62$ ), to the 'forest border' ( $51.9 \pm 38.3 \%$, range: $0.0-98.2 \%$, $n=20)$, and to the 'forest' habitat $(42.2 \pm 41.6 \%$, range: $0.0-96.2 \%, n=16)$. We believe this is a consequence of the presence of roots at the forest habitat, as entangled hatchlings were frequently observed upon nest excavations. It should be noted that nests in this study 
were relatively protected from the destructive action of nesting females, such that these parameters may be slightly overestimated.

\section{Sex ratio estimates and hatchling size}

We identified the sex of 131 hatchlings from 27 nests, with an average of $4.9 \pm 0.4$ hatchlings per nest (Table S3). Male hatchlings were significantly larger $(4.95 \pm 0.19 \mathrm{~cm}$, range: $4.44-5.33 \mathrm{~cm}, \mathrm{~N}=83)$ than females $(4.73 \pm 0.18 \mathrm{~cm}$, range: $4.26-5.11 \mathrm{~cm}, \mathrm{~N}=48$, $\left.t_{(95)}=-6.542, p<0.0001\right)$. The beginning of the TSP was $2.0 \pm 0.7$ days later than the start of the $\mathrm{IP}_{\text {mid }}$ (range: $0.8-3.2$ days), and the end of the TSP was $3.3 \pm 1.1$ days later than the end of the $\mathrm{IP}_{\text {mid }}$ (range: 2 - 5 days). Thus, the mean length of the TSP was highly coincident with the mean length of the $I P_{\text {mid }}$ (differing only by $1.3 \pm 0.6$ days), justifying the use of the 18-day average to predict the incubation temperature felt by clutches during the critical period of gonad differentiation. Additionally, the resulting difference in mean incubation temperatures between the TSP and the $\mathrm{IP}_{\text {mid }}$ was negligible; $0.3 \pm 0.1 \stackrel{\circ}{\circ} \mathrm{C}$ (range: $0.0-0.5$ $\left.{ }^{\circ} \mathrm{C}\right)$. All three covariates: i) IP ${ }_{\text {mid }}$ mean incubation temperature, ii) TSP mean incubation temperature, and iii) IP (to hatching) had a significant effect on expected sex ratio, with $P<$ 0.0001 . We used the logistic equation with TSP mean temperatures as the independent variable to estimate sex ratios across habitats and nesting seasons, as this model had smaller residual deviance (null deviance of GLMs $=127.9$, residual deviance of GLMs using i) $I P_{\text {mid }}$ mean temperatures $=56.8$, ii) $\mathrm{TSP}$ mean temperatures $=56.0$, iii) $\left.I P=62.9\right)$. The pivotal temperature was $29.4 \stackrel{\circ}{\circ}$, and the TRT ranged from $27.6-31.4 \stackrel{\circ}{\circ}$ (Fig. 3a). The IP equivalent to the pivotal temperature was 55.1 days (Fig. 3b). We estimated that $47.7 \%$ (95\% Cl: $36.7-58.3 \%)$ and $44.5 \%(95 \% \mathrm{Cl}: 33.8-55.4 \%)$ of hatchlings that were produced in 2013 and 2014, respectively, were male (Fig. 4). These estimates were reduced by 3.5\%, when considering the emergence success at each habitat (i.e. $44.2 \%$ and $40.9 \%$ postemerged males for 2013 and 2014, respectively). The proportion of male offspring produced was higher in the western beach sections (Fig. 1.b). Both the nesting habitat and clutch date influenced sex ratios. The mean expected proportion of males for both years at the 'open 
sand' was 29.5\% (95\% Cl: 20.2 - 40.9), at the 'forest border' was 56.6\% (95\% Cl: 43.5 $68.3 \%)$, and the 'forest' was $90.3 \%(95 \% \mathrm{Cl}: 79.2-95.5 \%)$. The sex ratio at the 'forest habitat' was always male-biased (Fig. 5), and a higher proportions of males were produced during the month of August (Fig. 4).

\section{Discussion}

We report here the first field-based estimates of primary sex ratio, pivotal temperature and transitional range of temperatures (TRT), from one of the major green turtle nesting rookeries worldwide, largest in the Southern Atlantic distinct population segment (DPS, Seminoff et al. 2015, Fig. 6). We found temporal and spatial heterogeneity in incubation conditions, leading to variation in estimated sex ratios, but an overall balanced primary sex ratio when the entire nesting season was considered. This estimates diverge from the primarily reported female-biased hatchling sex ratios at most rookeries. Our site-specific sex ratio curve enabled us to generate robust population-specific estimates, and can be applied for future monitoring of climate change impacts on the primary sex ratio. Insights gained from this work have broad application on the conservation management of marine turtle nesting habitats, and will specifically inform local decision makers towards an improved management of the marine protected area (MPA) of João Vieira and Poilão. We recommend conservation actions, and highlight a way forward to more fully understand the full scope of population resilience to climate change, and its potential for adaptation.

\section{Population-specific pivotal temperature and TRT}

The pivotal temperature estimated here was similar to recent values found for other green turtle populations (Broderick et al., 2000; Godfrey and Mrosovsky, 2006; Godley et al., 2002). This parameter alone however, is insufficient to predict primary sex ratios; accounting for the TRT is critical to characterize the population's response to incubation temperatures (Mrosovsky and Pieau, 1991; Hulin et al., 2009). A wider TRT will result in more mixedsexed clutches, and a wider range of temperatures within which heritability may influence 
offspring sex ratio (Bull et al., 1982; Hulin et al., 2009). Thus, populations with wider TRT have a lower risk of sex ratio bias under climate change (Hulin et al., 2009). A narrow TRT, on the other hand, leads to mostly single-sex nests, and even a slight change in incubation temperatures can have a dramatic impact on primary sex ratios, if the thermal conditions that allow for differentiation of both sexes ceases to be available (Mrosovsky and Pieau, 1991; Hulin et al., 2009). Nevertheless, few studies have estimated population-specific pivotal temperatures, and the TRT is rarely reported (Hulin et al. 2009). Typically, laboratory-derived curves are applied to infer primary sex ratios in the wild. However, because these curves rely on a small number of clutches (2-4 clutches, Mrosovsky 1988; Godfrey et al. 1999; Mrosovsky et al. 2002; Godfrey \& Mrosovsky 2006), exposed to less variable incubation conditions than those in the nesting beach, they have resulted in steep logistic curves with narrow TRTs, which may not reflect the real population variability and resilience. Here we estimated a TRT of $3.8^{\circ} \mathrm{C}$, suggesting that even with substantial increases in incubation temperatures (i.e. $2-3^{\circ} \mathrm{C}$, IPCC 2013) some nests would continue to produce males.

\section{Within-population variability on primary sex ratio response}

We found inter-clutch variation on the sex ratio response to mean incubation temperatures and to incubation period, similar to other field studies (Godfrey and Mrosovsky, 1997; Godley et al., 2002; King et al., 2013; Mrosovsky et al., 1999; Spotila et al., 1987; Wyneken and Lolavar, 2015). Such variation has been attributed to the effect of fluctuating temperatures on embryo development (Girondot et al. 2010). However, this should not be the case here, as we accounted for the embryo thermal reaction norm to estimate the beginning and end of the thermosensitive periods (TSP, Girondot \& Kaska, 2014). Interestingly, these were mostly coincident with the middle third of the incubation, which normally is expected under constant temperature environments (Bull, 1983), possibly due to the buffering effect against sudden temperature changes facilitated by the depth of the green turtle nests (Kaska et al., 1998). Both the spatial variation in incubation temperatures within clutches $\left(<1^{\circ} \mathrm{C}\right.$, decreasing from the top to the bottom, Kaska et al. 1998; Booth \& Astill 2001), and our small sample size 
413 (inherent to studies involving lethal sampling of hatchlings), may contribute to some of the

414 variation, but are unlikely to explain more atypical observations (e.g. $100 \%$ males under a TSP mean incubation temperature of $\left.30.3^{\circ} \mathrm{C}\right)$. Heritability, on the other hand, could be a more reasonable explanation, as similar within-population divergence is seen under constant incubation conditions (Bull et al., 1982; Mrosovsky, 1988). Alternatively, overlooked environmental parameters could be influencing hatchling sex. Recently, moisture was shown to override the effect of temperature on gonad differentiation; such that clutches incubated at female-biased temperatures, but with high humidity, produced more males than expected (Wyneken and Lolavar, 2015). Relative humidity is likely an important attribute of nests at Poilão, given the coincidence between the nesting and the rainy seasons. Moreover, the groundwater level after heavy rain episodes or spring tides is sufficiently high, that accumulated water can be seen inside abandoned nest chambers and body pits at areas with low elevation. An interaction between the effects of humidity and those of heritability, on the mechanisms of TSD, may be driving the observed variation within the TRT. Most important, both the variability in sex ratio response to incubation temperatures, and the wide TRT, are suggestive of resilience and potential for adaptation to climate change. It should be noted that the observed variation is not expected to bias sex ratio estimations, as the atypical values (i.e. more males than predicted under 'female-biased' temperatures, and vice versa), to some extent, cancelled each other out, because incubation temperatures during the TSP are fairly even distributed above and below the pivotal temperature at Poilão (Mrosovsky et al., 1999).

\section{Temporal and spatial refugia: resilience and adaptation to climate change}

Male hatchling production varied greatly over relatively small spatial scales; both from the exposed beach area to the dense vegetation (increasing from $30 \%$ to $91 \%$ ), and from the east to the west beach sections (increasing from 35\% to 56\%); and over short temporal scales. Differences in sand temperature between nearby beaches have been attributed to sand albedo (Godley et al. 2002; Fuller et al. 2013), and beach orientation (Booth \& 
441 Freeman 2006; Fuentes et al. 2010a). At Poilão there is no marked difference in sand color

442 between west and east sections, however, and beach orientation changes within each section. Instead, we hypothesize that this variation is driven by distance to the high tide line, as the western beach sections are narrower, so that nests are on average closer to the sea experiencing cooler temperatures (Fuentes et al. 2010a). Both the cooling effect of vegetation cover (Kamel, 2013; Janzen and Janzen, 2016), and rainfall (Godfrey et al., 1996; Houghton et al., 2007; Lolavar and Wyneken, 2015) on incubation temperatures have been previously recognized. This emphasizes the importance of accounting for the spatial and temporal distribution of nesting when estimating population primary sex ratios. The heterogeneity found here, across space and time, suggests that nesting females at Poilão may very well be capable of adaptation through phenotypic plasticity, if air temperatures and/or changes in precipitation lead to unfavorable incubation conditions. For example, adjusting the start of the nesting season, to have peak activity coinciding with the colder months (December and January) would enhance male hatchling production, and likely clutch survival under future global warming scenarios, as high incubation temperatures have been shown to lower survival of clutches (Godley et al. 2001a; Santidrián Tomillo et al. 2014; Hays et al. 2017). Changes in nesting phenology in response to climate change have been reported, however it remains unclear whether the start of nesting is triggered by the sea surface temperatures at breeding sites (Weishampel et al., 2004), or at foraging grounds (Mazaris et al., 2009). Additionally, other aspects influence sea turtle reproductive phenology, such as availability of food and energy allocated for reproduction (Broderick et al., 2001b), making predictions of phenological adaptations to climate change a challenge. Another possible way for females to adapt would be through nest-site selection, as some TSD species seem to adjust their nesting site to achieve optimal thermal conditions (Doody et al., 2006; Mitchell et al., 2013), although others have displayed behaviors that increased, rather than minimize, their vulnerability to warmer temperatures (Telemeco et al., 2016). Interestingly, individual inter-annual consistence in nest-site selection has been observed in sea turtles (Kamel \& Mrosovsky 2006). This provides scope for natural selection to occur, as 
females choosing to nest at cooler sites will probably have enhanced fitness under future global warming scenarios (Hays et al., 2017). There may be a trade-off however, between improved thermal conditions and reduced emergence success, as we found the latter to be significantly lower at vegetated areas.

\section{Primary sex ratio and implications for breeding sex ratio}

Overall we estimated a balanced seasonal primary sex ratio. This may imply a male-biased operational (breeding) sex ratio (OSR) for the green turtle population at Poilão, as several populations with female-biased primary sex ratios have been found to have 'balanced' OSRs (Wright et al. 2012a; Rees et al. 2013; Stewart \& Dutton 2014). These discrepancies resulting to some extent from males breeding more frequently than females (James et al., 2005; Hays et al., 2014), compensating partially for female-biased effective population sex ratios. However, at least one study has shown that a balanced OSR from a rookery with highly female-biased hatchling sex ratio was not due to sex-specific migratory strategies (Wright et al. 2012b). Moreover, balanced juvenile sex ratios, when female-biased were expected, have also been reported (Casale et al., 2006), leading to the hypothesis of differential survival between female and male post-hatchlings (Wright et al., 2012b). Malebiased incubation temperatures typically generate larger hatchlings with superior locomotor abilities, more likely to evade predators (Booth and Evans, 2011; Kobayashi et al. 2017). Males were also larger in our study, and ghost crabs preferentially prey on smaller hatchlings here (Rebelo et al., 2011). On the other hand, clutches laid under the vegetation are at greater distances from the water line, and emerging hatchlings may have poorer orientation skills (Kamel and Mrosovsky 2004), further increasing the length of time they spend exposed to land predators (e.g. ghost crabs, palm nut vultures; Rebelo et al., 2011, Carneiro et al., 2017). Finally, some inconsistencies between predicted hatchling sex ratios and observed juvenile and adult sex ratios may derive from poor primary sex ratio estimations, not accounting for population-specific pivotal temperatures and TRT. At any rate Poilão produces a significant number of adult males, which may contribute to a wider 
497 Eastern Atlantic metapopulation (Roberts et al. 2004; James et al. 2005; Wright et al.

498 2012a), endowing it of global importance for the future of the green turtle in a warming world,

499

500

501

502

503

504

505

506

507

508

509

510

511

512

513

514

515

516

517

518

519

520

521

522

523

524 particularly given the scale of magnitude of this population (> one million hatchlings produced every year). Considering that some TSD-species populations are expected to produce $100 \%$ female offspring under predicted climate change scenarios (Hawkes et al., 2007; Patino-Martinez et al. 2012; Laloë et al. 2014), it is of global importance to identify nesting rookeries with high male hatchling production, as these are likely to become of higher conservation value in the future.

\section{Conclusions}

Significant information gaps on marine turtle primary sex ratios exist, both at a species and at a geographic level. Adding Poilão to the regional map of green turtle primary sex ratios will contribute to assessments of the metapopulation. There are now robust estimates of this population parameter from the three main nesting rookeries within the Southern Atlantic DPS, but estimates are still lacking from other significant rookeries (e.g. Aves Island, French Guiana and Trindade Island, Fig. 6).

A key outcome of this study is the evidence supporting the importance of native vegetation for population resilience. Poilão currently enjoys a full protection of its habitat, thanks to national laws and its sacred status among the local communities (Catry et al., 2009). However, on nearby islands where numerous of clutches are also laid annually (IBAP unpublished data), significant deforestation for slash-and-burn agriculture has taken place in recent years. Forest conservation and the enforcement of rules banning the felling of trees inside the MPA are critical actions, and of broad impact, contributing to the conservation of both sea turtles and other species using the coastal forest habitat, notably the globally endangered Timneh parrots Psittacus timneh (Lopes 2014). Lastly, although the nesting population at Poilão seems resilient to warming temperatures, other aspects of climate change must be considered. Thermal expansion of the ocean will increase the mean sea level, causing inundation and erosion of coastal areas, worsened 
525 further by predicted increased storm intensity. Extensive losses of sea turtle nesting habitat

526 have been predicted under median SLR scenarios ( Baker et al. 2006; Fuentes et al. 2010b;

527 Katselidis et al. 2014). It is thus critical to investigate how predicted future SLR will impact

528 the low lying nesting habitat at Poilão and neighboring islands, to fully understand how

529 resilient this population may be to climate change.

530

\section{Acknowledgements}

532 We thank the numerous people that participated in the fieldwork, particularly Quintino

533 Tchantchalam (Director of the JVPMNP, IBAP), Mohamed Henriques (ISPA), António José

534 Pires (IBAP), Emanuel Dias (IBAP), Amadeu Mendes de Almeida (CIPA - GB), Bucar Indjai

535 (INEP - GB), Betânia Ferreira Airaud (ATM, Portugal), Dominic Tiley (University of Exeter),

536 the IBAP park rangers (César Banca, Paulino da Costa, Carlos Banca, Santinho da Silva,

537 Saído Gomes, Seco Cardoso, João Pereira and Tio Zé), and the volunteers from the local

538 village of Ambeno, Canhabaque Island (Sana, Beto, Matchu, Rapaz, Sene, Correia, Tó,

539 Cândido, Neto, laia, Chiquinho, Mário, and Joaquim). This work was conducted under the

540 license and supervision of the Institute for the Biodiversity and Protected Areas of Guinea-

541 Bissau (IBAP). Sampling and export permits were obtained by IBAP-GB, and imported under

542 CITES license 13-PT-LX0006/P, emitted by the Institute for Nature Conservation and

543 Forests (ICNF-PT). Funding: research was funded by the MAVA Foundation, the Rufford

544 Foundation (RSG12317-1, RSG16357-2), and the Portuguese Foundation for Science and

545 Technology through the strategic projects PEst-OE/BIA/UI0329/2014 granted to cE3c, and

546 UID/MAR/04292/2013 granted to MARE, project IF/00502/2013/CP1186/CT0003, and the

547 grant awarded to ARP (fellowship SFRH/BD/85017/2012).

References

550 Abella Perez E, Marco A, Martins S, Hawkes LA (2016) Is this what a climate change-

551 resilient population of marine turtles looks like? Biol Conserv 193: 124-132.

552 doi:10.1016/j.biocon.2015.11.023 
Ackerman RA (1997) The nest environment and the embryonic development of sea turtles. In The Biology of Sea Turtles, in: Lutz, P.L., Musick, J.A. (Eds.), The Biology of Sea Turtles. CRC Press LLC, Boca Raton, pp. 83-106

ATM/MARAPA (2016) Programa de Conservação de Tartarugas Marinhas na llha de São Tomé - Programa Tatô. Relatório Técnico 2015/2016. 30 pp.

Baker JD, Littnan CL, Johnston DW (2006) Potential effects of sea level rise on the terrestrial habitats of endangered and endemic megafauna in the Northwestern Hawaiian Islands. Endang Species Res 2: 21-30. doi:10.3354/esr002021

Bellini C, Santos AJ, Grossman A, Marcovaldi MA, Barata PC (2013) Green turtle (Chelonia mydas) nesting on Atol das Rocas, north-eastern Brazil, 1990-2008. J Mar Biol Assoc UK 93: 1117-32. doi: 10.1017/S002531541200046X

Booth DT, Astill K (2001) Temperature variation within and between nests of the green sea turtle, Chelonia mydas (Chelonia: Cheloniidae) on Heron Island, Great Barrier Reef. Aust J Zool 49: 71-84. doi: 10.1016/j.biocon.2015.11.023

Booth DT, Freeman C (2006) Sand and nest temperatures and an estimate of hatchling sex ratio from the Heron Island green turtle (Chelonia mydas) rookery, Southern Great Barrier Reef. Coral Reefs 25: 629-633. doi:10.1007/s00338-006-0135-4

Booth DT, Evans A (2011) Warm water and cool nests are best. How global warming might influence hatchling green turtle swimming performance. PLoS One 6: e23162. doi:10.1371/journal.pone.0023162

Braun McNeill J, Avens L, Goodman Hall A, Goshe LR, Harms CA, Owens DW (2016) Female-Bias in a Long-Term Study of a Species with Temperature-Dependent Sex Determination: Monitoring Sex Ratios for Climate Change Research. PLoS One 11: e0160911. doi:10.1371/journal.pone.0160911

Broderick AC, Godley BJ, Reece S, Downie JR (2000) Incubation periods and sex ratios of green turtles: highly female biased hatchling production in the Eastern Mediterranean. Mar Ecol Prog Ser 202: 273-281. doi:10.3354/meps202273

Broderick AC, Godley BJ, Hays GC (2001a) Metabolic heating and the prediction of sex 
ratios for green turtles (Chelonia mydas). Physiol Biochem Zool 74: 161-170 STMetabolic heating and the prediction. doi:10.1016/S0006-3207(00)00107-5

Broderick AC, Godley BJ, Hays GC (2001b) Trophic status drives interannual variability in nesting numbers of marine turtles. Proc Biol Sci 268: 1481-7. doi:10.1098/rspb.2001.1695

Brook BW, Sodhi NS, Bradshaw CJA (2008) Synergies among extinction drivers under global change. Trends Ecol Evol 23: 453-460. doi:10.1016/j.tree.2008.03.011

Bull JJ, Vogt RC, McCoy CJ (1982) Heritability of sex ratio in turtles with environmental sex determination. Evolution (N. Y) 36: 326-332

Bull JJ (1983) Evolution of sex determining mechanisms, Benjamin/C. ed. Menlo Park, Calif. Candan O, Kolankaya D (2016) Sex ratio of green turtle (Chelonia mydas) hatchlings at Sugözü, Turkey: higher accuracy with pivotal incubation duration. Chelonian Conserv Biol 15: 102-108. doi:10.2744/CCB-1132.1

Casale P, Gerosa G, Yerli S (2000) Female-biased primary sex ratio of the green turtle, Chelonia mydas, estimated through sand temperatures at Akyatan, Turkey. Zool Middle East 20: 37-46. doi:10.1080/09397140.2000.10637810

Casale P, Lazar B, Pont S, Tomás J, Zizzo N, Alegre F, Badillo J, Summa AD, Freggi D Lackovic G, Raga JA, Rositani L, Tvrtkovic N, Tomas J, Di Summa A (2006) Sex ratios of juvenile loggerhead sea turtles Caretta caretta in the Mediterranean Sea. Mar Ecol Prog Ser 324: 281-285. doi:10.3354/meps324281

Carneiro C, Henriques M, Barbosa C, Tchantchalam Q, Regalla A, Patrício AR, Catry P (2017) Ecology and behaviour of Palm-nut Vultures Gypohierax angolensis in the Bijagós Archipelago, Guinea-Bissau. Ostrich In press. doi:10.2989/00306525.2017.1291540

Catry P, Barbosa C, Indjai B, Almeida A, Godley BJ, Vié JC (2002) First census of the green turtle at Poilão, Bijagós Archipelago, Guinea-Bissau: the most important nesting colony on the Atlantic coast of Africa. Oryx 36: 400-403. doi:doi:10.1017/S0030605302000765 Catry P, Barbosa C, Paris B, Indjai B, Almeida A (2009) Status, Ecology, and Conservation 
of Sea Turtles in Guinea-Bissau. Chelonian Conserv Biol 8: 150-160. doi: 10.2744/CCB-0772.1

Doody JS, Guarino E, Georges A, Corey B, Murray G, Ewert M (2006) Nest site choice compensates for climate effects on sex ratios in a lizard with environmental sex determination. Evol Ecol 20: 307-330. doi:10.1007/s10682-006-0003-2

Esteban N, Laloë JO, Mortimer JA, Guzman AN, Hays GC (2016) Male hatchling production in sea turtles from one of the world's largest marine protected areas, the Chagos Archipelago. Sci Rep 6: 20339. doi:10.1038/srep20339

Fisher RA (1930) The genetical theory of natural selection. Oxford.

Fuentes MPB, Maynard JA, Guinea M, Bell IP, Werdell PJ, Hamann M (2009) Proxy indicators of sand temperature help project impacts of global warming on sea turtles in northern Australia. Endanger Species Res 9: 33-40. doi: 10.3354/esr00224

Fuentes MPB, Hamann M, Limpus CJ (2010a) Past, current and future thermal profiles of green turtle nesting grounds: Implications from climate change. J Exp Mar Bio Ecol 383: 56-64. doi:10.1016/j.jembe.2009.11.003

Fuentes MPB, Limpus CJ, Hamann M, Dawson J (2010b) Potential impacts of projected sea-level rise on sea turtle rookeries. Aquat Conserv Mar Freshw Ecosyst 20: 132-139. doi:10.1002/aqc. 1088

Fuller WJ, Godley BJ, Hodgson DJ, Reece SE, Witt MJ, Broderick AC (2013) Importance of spatio-temporal data for predicting the effects of climate change on marine turtle sex ratios. Mar Ecol Prog Ser 488: 267-274. doi:10.3354/meps 10419

García-Cruz MA, Lampo M, Peñaloza CL, Kendall WL, Solé G, Rodríguez-Clark KM (2015) Population trends and survival of nesting green sea turtles Chelonia mydas on Aves Island, Venezuela. Endanger Species Res 29:103-116. doi: 10.3354/esr00695

Georges A (2013) For reptiles with temperature-dependent sex determination, thermal variability may be as important as thermal averages. Anim Conserv 16: 493-494. doi:10.1111/acv.12080

Girondot M, Ben Hassine S, Sellos C, Godfrey M, Guillon JM (2010) Modeling Thermal 
Influence on Animal Growth and Sex Determination in Reptiles: Being Closer to the Target Gives New Views. Sex Dev 4: 29-38. doi: 1 10.1159/000280585

Girondot M, Kaska Y (2014) A model to predict the thermal reaction norm for the embryo growth rate from fi eld data. J Therm Biol 45: 96-102. oi:10.1016/j.jtherbio.2014.08.005

Godfrey MH, Barreto R, Mrosovsky N (1996) Estimating past and present sex ratios of sea turtles in Suriname. Can J Zool 74: 267-277. doi: 10.1139/z96-033

Godfrey MH, Mrosovsky N (1997) Estimating the time between hatching of sea turtles and their emergence from the nest. Chelonian Conserv Biol 2: 581-584

Godfrey MH, D’Amato AF, Marcovaldi MÂ, Mrosovsky N (1999) Pivotal temperature and predicted sex ratios for hatchling hawksbill turtles from Brazil. Can J Zool 77: 14651473. doi:10.1139/z99-117

Godfrey MH, Mrosovsky N (2006) Pivotal temperature for green sea turtles, Chelonia mydas, nesting in Suriname. Herpetol J 16: 55-61

Godley BJ, Broderick AC, Downie JR, Glen F, Houghton JD, Kirkwood I, Reece S, Hays GC (2001a) Thermal conditions in nests of loggerhead turtles: Further evidence suggesting female skewed sex ratios of hatchling production in the Mediterranean. J Exp Mar Bio Ecol 263: 45-63. doi:10.1016/S0022-0981(01)00269-6

Godley BJ, Broderick AC, Mrosovsky N (2001b) Estimating hatchling sex ratios of loggerhead turtles in Cyprus from incubation durations. Mar Ecol Prog Ser 210: 195201. doi:10.3354/meps210195

Godley BJ, Broderick AC, Hays GC (2001c) Nesting of green turtles (Chelonia mydas) at Ascension Island, South Atlantic. Biol Conserv 97: 151-158. doi:10.1016/S0006$3207(00) 00107-5$

Godley BJ, Broderick AC, Glen F, Hays G (2002) Temperature-dependent sex determination of Ascension Island green turtles. Mar Ecol Prog Ser 226: 115-124. doi:10.3354/meps226115

Hawkes LA, Broderick AC, Godfrey MH, Godley BJ (2007) Investigating the potential impacts of climate change on a marine turtle population. Glob Chang Biol 13: 923-932. 
Hawkes LA, Broderick AC, Godfrey MH, Godley BJ (2009) Climate change and marine turtles. Endanger Species Res 7: 137-154. doi:10.3354/esr00198

Hays GC, Mazaris AD, Schofield G (2014) Different male vs. female breeding periodicity helps mitigate offspring sex ratio skews in sea turtles. Orig Res Artical 1:1-9. doi:10.3389/fmars.2014.00043

Hays GC, Mazaris AD, Schofield G, Laloë JO (2017) Population viability at extreme sex-ratio skews produced by temperature-dependent sex determination. Proc R Soc London B Biol Sci 284: 20162576. doi:10.1098/rspb.2016.2576

Honarvar S, Fitzgerald DB, Weitzman CL, Sinclair EM, Esara Echube JM, O'Connor M, Hearn GW (2016) Assessment of Important Marine Turtle Nesting Populations on the Southern Coast of Bioko Island, Equatorial Guinea. Chelonian Conserv Biol 15: 79-89. doi: $10.2744 / C C B-1194.1$

Houghton JDR, Myers AE, Lloyd C, King RS, Isaacs C, Hays GC (2007) Protracted rainfall decreases temperature within leatherback turtle (Dermochelys coriacea) clutches in Grenada, West Indies: Ecological implications for a species displaying temperature dependent sex determination. J Exp Mar Bio Ecol: 345, 71-77. doi:10.1016/j.jembe.2007.02.001

Hulin V, Delmas V, Girondot M, Godfrey MH, Guillon JM (2009) Temperature-dependent sex determination and global change: are some species at greater risk? Oecologia 160: 493-506. doi:10.1007/s00442-009-1313-1

James MC, Eckert SA, Myers RA (2005) Migratory and reproductive movements of male leatherback turtles (Dermochelys coriacea). Mar Biol 147: 845-853. doi:10.1007/s00227-005-1581-1

Janzen FJ, Janzen FJ (2016) Vegetational Cover Predicts the Sex Ratio of Hatchling Turtles in Natural Nests. Ecology 75: 1593-1599. doi: 10.2307/1939620

Kamel SJ, Mrosovsky N (2004) Nest site selection in leatherbacks, Dermochelys coriacea: individual patterns and their consequences. Anim Behav 68: 357-366. 
doi:10.1016/j.anbehav.2003.07.021

Kamel SJ, Mrosovsky N (2006a) Deforestation : Risk of Sex Ratio Distortion in Hawksbill Sea Turtles. Ecol Appl 16: 923-931. doi: 10.1890/10510761(2006)016[0923:DROSRD]2.0.CO;2

Kamel SJ, Mrosovsky N (2006b) Inter-seasonal maintenance of individual nest site preferences in hawksbill sea turtles. Ecology 87: 2947-2952. doi:10.1890/00129658(2006)87[2947:IMOINS]2.0.CO;2

Kamel SJ (2013) Vegetation cover predicts temperature in nests of the hawksbill sea turtle: Implications for beach management and offspring sex ratios. Endanger Species Res 20: 41-48. doi:10.3354/esr00489

Kaska Y, Downie R, Tippett R, Furness RW (1998) Natural temperature regimes for loggerhead and green turtle nests in the eastern Mediterranean. Can J Zool 76: 723729. doi:10.1139/z97-245

Kaska Y and Downie R (1999) Embryological development of sea turtles (Chelonia mydas, Caretta caretta) in the Mediterranean. Zool Middle East 19: 55-69. doi:10.1080/09397140.1999.10637796

Kaska Y, Ilgaz Ç, Özdemir A, Başkale E, Türkozan O, Baran I, Stachowitsch M (2006) Sex ratio estimations of loggerhead sea turtle hatchlings by histological examination and nest temperatures at Fethiye beach, Turkey. Naturwissenschaften 93: 338-343. doi:10.1007/s00114-006-0110-5

Katselidis KA, Schofield G, Stamou G, Dimopoulos P, Pantis JD (2012) Females first? Past, present and future variability in offspring sex ratio at a temperate sea turtle breeding area. Anim Conserv 15: 508-518. doi:10.1111/j.1469-1795.2012.00543.x

Katselidis KA, Schofield G, Stamou G, Dimopoulos P, Pantis JD (2014) Employing sea-level rise scenarios to strategically select sea turtle nesting habitat important for long-term management at a temperate breeding area. J Exp Mar Bio Ecol 450: 47-54. doi:10.1016/j.jembe.2013.10.017

King R, Cheng WH, Tseng CT, Chen H, Cheng IJ (2013) Estimating the sex ratio of green 
sea turtles (Chelonia mydas) in Taiwan by the nest temperature and histological methods. J Exp Mar Biol Ecol 445: 140-147. doi:10.1016/j.jembe.2013.03.016

Kobayashi S, Wada M, Fujimoto R, Kumazawa Y, Arai K (2017) The effects of nest incubation temperature on embryos and hatchlings of the loggerhead sea turtle: Implications of sex difference for survival rates during early life stages. J Exp Mar Biol Ecol 486: 274-281. doi: 10.1016/j.jembe.2016.10.020

Laloë JO, Cozens J, Renom B, Taxonera A, Hays GC (2014) Effects of rising temperature on the viability of an important sea turtle rookery. Nat Clim Change 4: 513-518. doi:

\subsection{8/NCLIMATE2236}

Laloë JO, Esteban N, Berkel J, Hays GC (2016) Sand temperatures for nesting sea turtles in the Caribbean: Implications for hatchling sex ratios in the face of climate change. J Exp Mar Biol Ecol 474: 92-99. doi:10.1016/j.jembe.2015.09.015

Lang JW, Andrews HV (1994) Temperature-Dependent Sex Determination in Crocodilians. J Exp Zool A Ecol Genet Physiol 44: 28-44. doi: 10.1002/jez.1402700105

LeBlanc AM, Drake KK, Williams KL, Frick MG, Wibbels T, Rostal DC (2012) Nest Temperatures and Hatchling Sex Ratios from Loggerhead Turtle Nests Incubated Under Natural Field Conditions in Georgia, United States. Chelonian Conserv Biol 11: 108-116. doi:10.2744/CCB-0915.1

Lolavar A, Wyneken J (2015) Effect of rainfall on loggerhead turtle nest temperatures, sand temperatures and hatchling sex. Endanger Species Res 28: 235-247. doi:10.3354/esr00684

Lopes D (2014) O Papagaio-Cinzento-de-Timneh, Psittacus timneh, no arquipélago dos Bijagós: Contribuições para o estudo do estatuto, ecologia e conservação de uma espécie ameaçada. MsC Thesis, University of Lisbon

Marcovaldi MÂ, Godfrey MH, Mrosovsky N (1997) Estimating sex ratios of loggerhead turtles in Brazil from pivotal incubation durations. Can J Zool 75: 755-770. doi: 10.1139/z97097

Matsuzawa Y, Sato K, Sakamoto W, Bjorndal KA (2002) Seasonal fluctuations in sand 
temperature: Effects on the incubation period and mortality of loggerhead sea turtle (Caretta caretta) pre-emergent hatchlings in Minabe, Japan. Mar Biol 140: 639-646. doi:10.1007/s00227-001-0724-2

Mazaris AD, Kallimanis AS, Tzanopoulos J, Sgardelis SP, Pantis JD (2009) Sea surface temperature variations in core foraging grounds drive nesting trends and phenology of loggerhead turtles in the Mediterranean Sea. J Exp Mar Biol Ecol 379: 23-27. doi:10.1016/j.jembe.2009.07.026

McClenachan L, Jackson JBC, Newman MJH (2006) Conservation implications of historic turtle beach loss nesting. Front Ecol Environ 4: 290-296. doi:10.1890/15409295(2006)4[290:CIOHST]2.0.CO;2

Melbourne BA and Hastings A (2008) Extinction risk depends strongly on factors contributing to stochasticity. Nature $454: 100-103$. doi:10.1038/nature06922

Metcalfe K, Didier Agamboué P, Augowet E, Boussamba F, Cardiec F, Fay JM, Formia A, Kema Kema JR, Kouerey C, Didier Koumba Mabert B, Maxwell SM, Minton G, Avery Mounguengui Mounguengui G, Moussounda C, Moukoumou N, Churley Manfoumbi J, Megne Nguema A, Nzegoue J, Parnell RJ, du Plessis P, Sounguet GP, Tilley D, Verhage S, Viljoen W, White L, Witt MJ, Godley BJ (2015) Going the extra mile : Ground-based monitoring of olive ridley turtles reveals Gabon hosts the largest rookery in the Atlantic. Biol Conserv 190: 14-22. doi:10.1016/j.biocon.2015.05.008

Miller JD, Limpus CJ (2003) Ontogeny of marine turtle gonads. The biology of sea turtles, 2, pp.199-224

Mitchell NJ, Allendorf FW, Keall SN, Daugherty CH, Nelson NJ (2010) Demographic effects of temperature-dependent sex determination: Will tuatara survive global warming? Glob Chang Biol 16: 60-72. doi:10.1111/j.1365-2486.2009.01964.x

Mitchell NJ, Janzen FJ (2010) Temperature-Dependent sex determination and contemporary climate change. Sex Dev 4: 129-140. doi:10.1159/000282494

Mitchell TS, Maciel JA, Janzen FJ (2013) Does sex-ratio selection influence nest-site choice in a reptile with temperature-dependent sex determination? Proc R Soc B Biol Sci 280: 
Mrosovsky N, Yntema CL (1980) Temperature dependence of sexual differentiation in sea turtles: implications for conservation practises. Biol Conserv 18: 271-280. doi: 10.1016/0006-3207(80)90003-8

Mrosovsky N (1988) Pivotal temperatures for loggerhead turtles (Caretta caretta) from northern and southern nesting beaches. Can J Zool 66: 661-669. doi:10.1139/z88-098

Mrosovsky N, Pieau C (1991) Transitional range of temperature, pivotal temperatures and thermosensitive stages for sex determination in reptiles. Amphibia-Reptilia 12: 169179. doi: $10.1163 / 156853891 \times 00149$

Mrosovsky N, Baptistotte C, Godfrey MH (1999) Validation of incubation duration as an index of the sex ratio of hatchling sea turtles. Can J Zool 77: 831-835. doi:10.1139/z99039

Mrosovsky N, Kamel SJ, Rees AF, Margaritoulis D (2002) Pivotal temperature for loggerhead turtles (Caretta caretta) from Kyparissia Bay, Greece. Can J Zool 80: 21182124. doi:10.1139/z02-204

Mrosovsky N, Kamel SJ, Diez CE, van Dam RP (2009) Methods of estimating natural sex ratios of sea turtles from incubation temperatures and laboratory data. Endanger Species Res 8: 147-155. doi:10.3354/esr00200

Patino-Martinez J, Marco A, Quiñones L, Hawkes L (2012) A potential tool to mitigate the impacts of climate change to the caribbean leatherback sea turtle. Glob Chang Biol 18: 401-411. doi:10.1111/j.1365-2486.2011.02532.x

Poloczanska ES, Limpus CJ, Hays GC (2009) Vulnerability of marine turtles to climate change. Adv Mar Biol 56: 151-211. oi:10.1016/S0065-2881(09)56002-6

R Development Core Team (2008) R: A language and environment for statistical computing. R Foundation for Statistical Computing, Vienna, Austria. www.r-project.org

Rebelo R, Barbosa C, Granadeiro J, Indjai B, Novais B, Rosa G, Catry P (2011) Can leftovers from predators be reliably used to monitor marine turtle hatchling sex-ratios? The implications of prey selection by ghost crabs. Mar Biol 159: 613-620. 
doi:10.1007/s00227-011-1839-8

Rees AF, Margaritoulis D, Newman R, Riggall TE, Tsaros P, Zbinden JA, Godley BJ (2013) Ecology of loggerhead marine turtles Caretta caretta in a neritic foraging habitat: Movements, sex ratios and growth rates. Mar Biol 160: 519-529. doi:10.1007/s00227$012-2107-2$

Rees AF, Barata PCR, Bjorndal KA, Bolten AB, Bourjea J, Broderick AC, Campbell LM, Cardona L, Carreras C, Casale P, Ceriani SA, Dutton PH, Eguchi T, Formia A, Fuentes MMPB, Fuller WJ, Girondot M, Godfrey MH, Hamann M, Hart KM, Hays GC, Hochscheid S, Kaska Y, Jensen MP, Mangel JC, Mortimer JA, Ng CKY, Nichols WJ, Phillott AD, Reina RD, Revuelta O, Schofield G, Seminoff JA, Shanker K, Tomás J, Van De Merwe JP, Van Houtan KS, Vander Zanden HB, Wallace BP, Work TM, Godley BJ (2016) Are we working towards global research priorities for management and conservation of sea turtles? Endanger Species Res 31: 337-382. doi:10.3354/esr00801

Reneker JL, Kamel SJ (2016) Climate Change Increases the Production of Female Hatchlings at a Northern Sea Turtle Rookery. Ecology 97: 257-3264. doi:10.1002/ecy. 1603

Roberts MA, Schwartz TS, Karl SA, August S (2004) Global population genetic structure and male-mediated gene flow in the green sea turtle (Chelonia mydas): analysis of microsatellite loci. Genetics 166: 1857-1870. doi:10.1534/genetics.166.4.1857

Santidrián Tomillo P, Oro D, Paladino FV, Piedra R, Sieg AE, Spotila JR (2014) High beach temperatures increased female-biased primary sex ratios but reduced output of female hatchlings in the leatherback turtle. Biol Conserv 176: 71-79. doi:10.1016/j.biocon.2014.05.011

Seminoff JA, Allen CD, Balazs GH, Dutton PH, Eguchi T, Haas HL, Hargrove SA, Jensen MP, Klemm DL, Lauritsen AM, MacPherson SL, Opay P, Possardt EE, Pultz SL, Seney EE, Van Houtan KS, Waples RS (2015) Status Review of the Green Turtle (Chelonia mydas) Under the U.S. Endangered Species Act. NOAA Technical Memorandum, NOAANMFS-SWFSC-539. $571 \mathrm{pp}$. 
Skiljan I (2012) IrfanView. URL http:// irfanview. tuwien. ac. at/. Retrieved June

Stewart KR, Dutton PH (2014) Breeding sex ratios in adult leatherback turtles (Dermochelys coriacea) may compensate for female-biased hatchling sex ratios. PLoS One 9: 1-5. doi:10.1371/journal.pone.0088138

Stocker L (2005) Practical wildlife care, 2nd edn. Blackwell, Oxford

Telemeco RS, Fletcher B, Levy O, Riley A, Rodriguez-Sanchez Y, Smith C, Teague C, Waters A, Angilletta MJ, Buckley LB (2016) Lizards fail to plastically adjust nesting behavior or thermal tolerance as needed to buffer populations from climate warming. Glob Chang Biol 23: 1075-1084. doi:10.1111/gcb.13476

Viets BE, Ewert MA, Talent LG, Nelson CE (1994) Sex-Determining Mechanisms in Squamate Reptiles. J Exp Zool 270: 45-56. doi:10.1002/jez.1402700106

Weber SB, Weber N, Ellick J, Avery A, Frauenstein R, Godley BJ, Sim J, Williams N, Broderick AC (2014) Recovery of the South Atlantic's largest green turtle nesting population. Biodivers Conserv 23: 3005-3018. doi:10.1007/s10531-014-0759-6

Weishampel JF, Bagley DA, Ehrhart LM (2004) Earlier nesting by loggerhead sea turtles following sea surface warming. Glob Chang Biol 10: 1424-1427. doi:10.1111/j.13652486.2004.00817.x

Witt MJ, Hawkes LA, Godfrey MH, Godley BJ, Broderick AC (2010) Predicting the impacts of climate change on a globally distributed species: the case of the loggerhead turtle. $\mathrm{J}$ Exp Biol 213: 901-911. doi:10.1242/jeb.038133

Wright LI, Stokes KL, Fuller WJ, Godley BJ, McGowan A, Snape R, Tregenza T, Broderick AC (2012a) Turtle mating patterns buffer against disruptive effects of climate change. Proc R Soc B Biol Sci 279: 2122-2127. doi: 10.1098/rspb.2011.2285 Wright LI, Fuller WJ, Godley BJ, McGowan A, Tregenza T, Broderick AC (2012b) Reconstruction of paternal genotypes over multiple breeding seasons reveals male green turtles do not breed annually. Mol Ecol 21: 3625-3635. doi:10.1111/j.1365294X.2012.05616.x

Wyneken J, Lolavar A (2015) Loggerhead sea turtle environmental sex determination: 
861 Implications of moisture and temperature for climate change based predictions for

862 species survival. J Exp Zool Part B Mol Dev Evol 324: 295-314.

$863 \quad$ doi:10.1002/jez.b.22620

864 Zbinden J, Davey C, Margaritoulis D, Arlettaz R (2007) Large spatial variation and female 865 bias in the estimated sex ratio of loggerhead sea turtle hatchlings of a Mediterranean 866 rookery. Endanger Species Res 3: 305-312. doi:10.3354/esr00058 

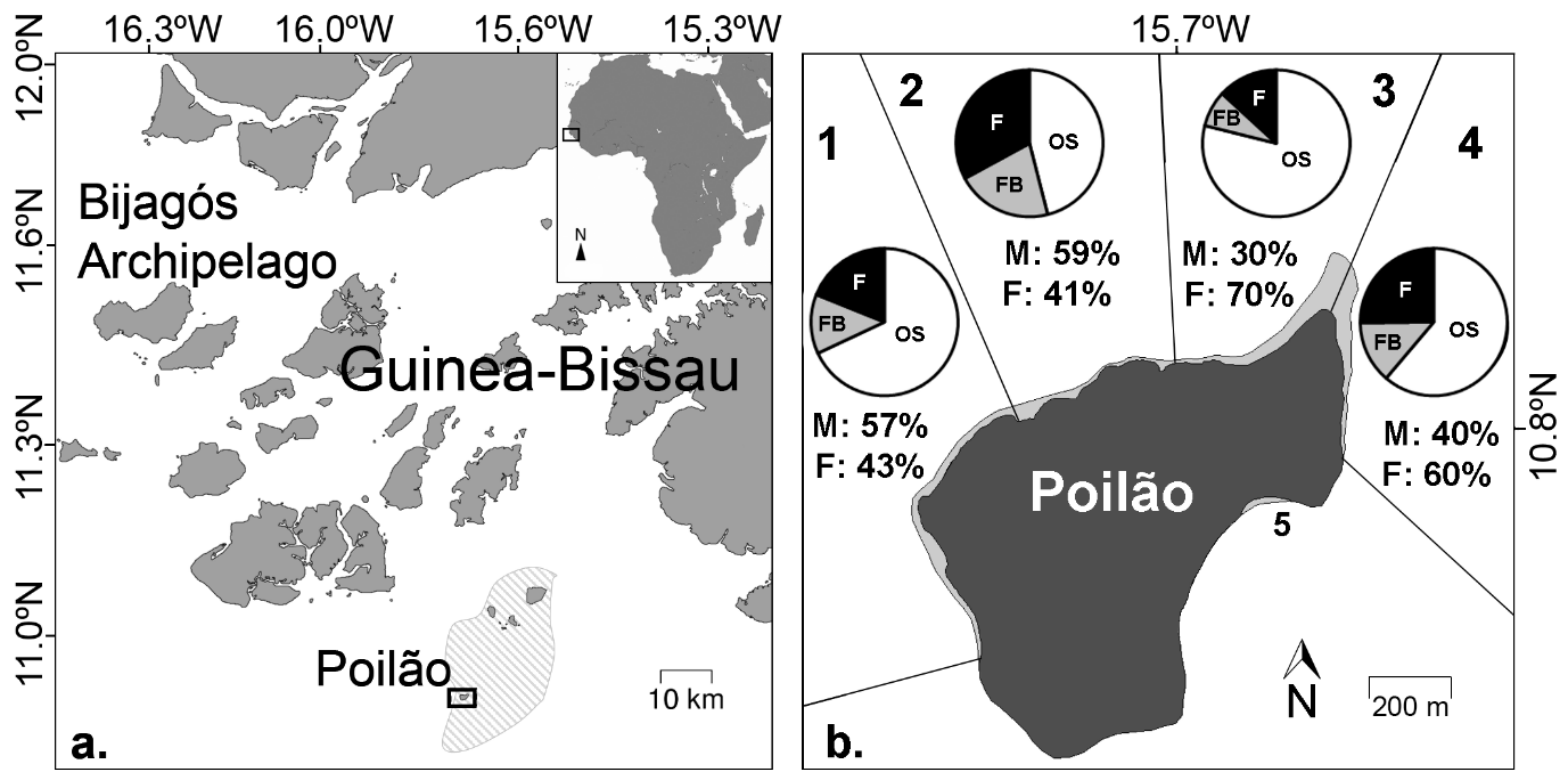

868

869

Figure 1a. Map of the Bijagós Archipelago, Guinea-Bissau: the João Vieira and Poilão

Marine National Park is represented by the striped area, and the black frame depicts Poilão

Island; b. Map of Poilão Island showing the four green turtle nesting beach sections monitored in this study (1 - Farol, 2 - Acampamento Oeste, 3 - Acampamento Este, 4 Cabaceira). Pie charts present the mean nesting distribution across three habitats: 'open sand' (OS: white), 'forest border' (FB: grey), and 'forest' (F: black), in each section. Estimated mean proportion of males $(M)$ and females $(F)$ produced in each section in 2013 and 2014 are given. Section 5 - Praia Militar, was not monitored in this study due to difficult access and the small proportion of nesting hosted there (Maps created using www.seaturtle.org/maptool). 
2013

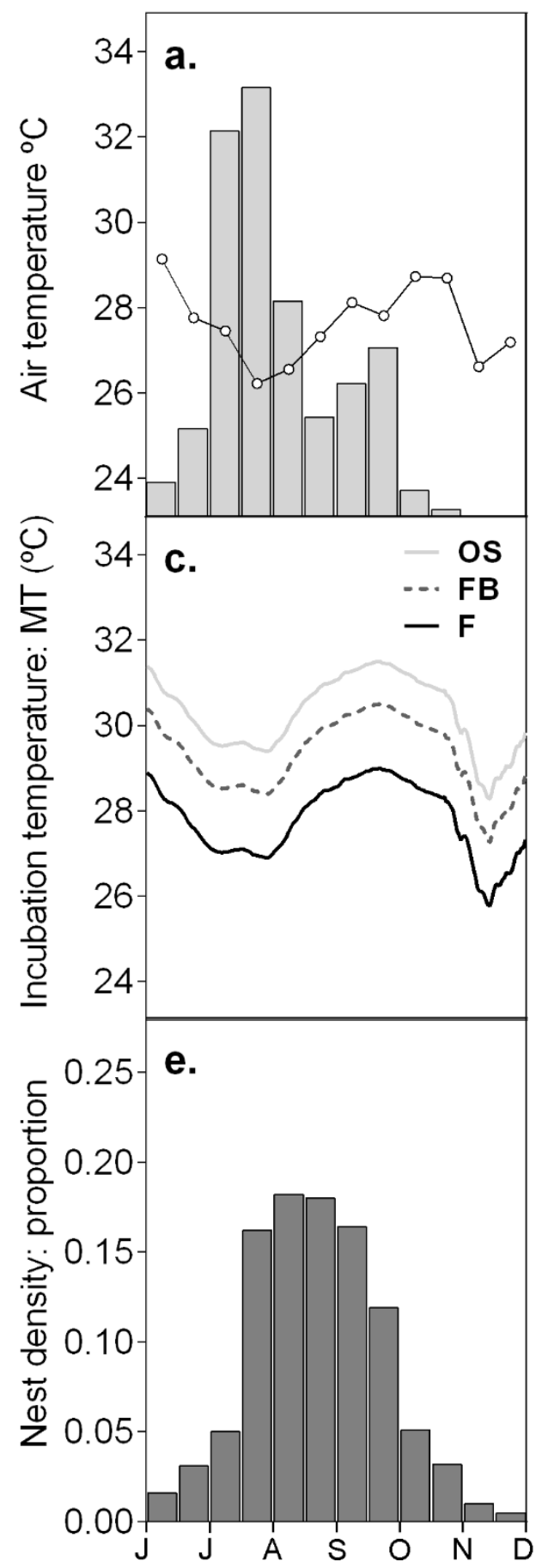

2014

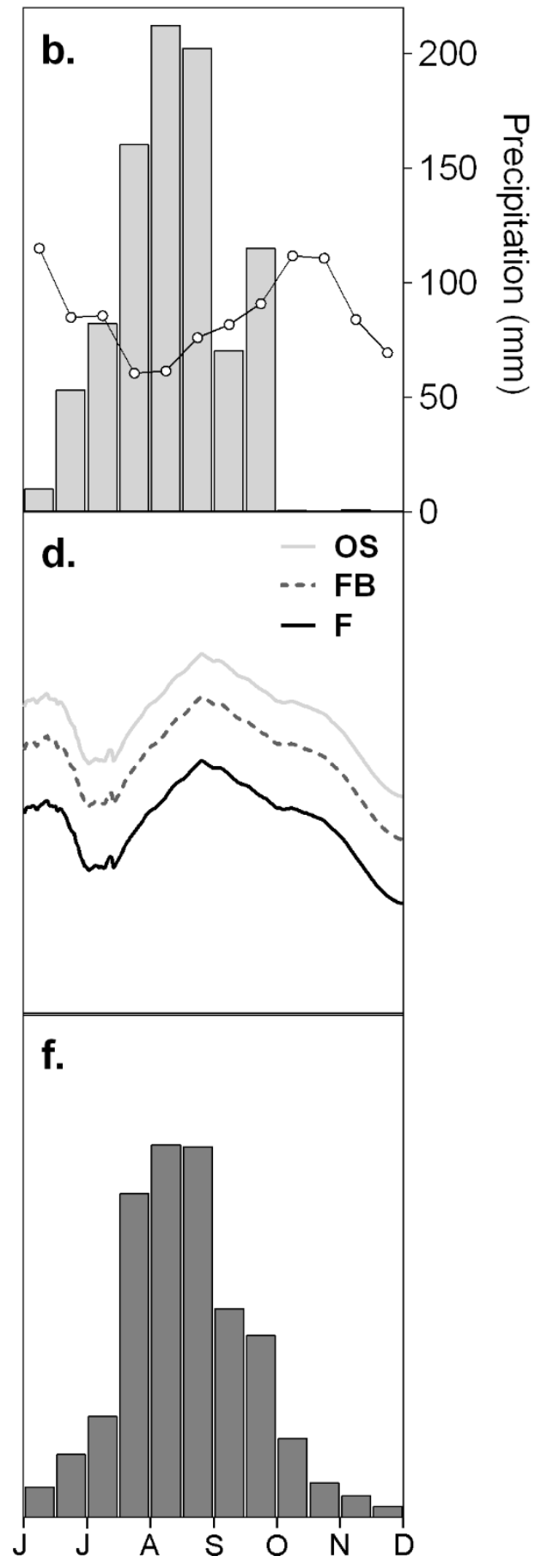

883 Figure 2a, b. Mean bi-weekly air temperature (open circles) and precipitation (bar) at Bissau

884 (http://cdo.ncdc.noaa.gov/CDO/cdo); c, d. estimated middle third mean incubation

885 temperatures experienced by green turtle clutches laid from 15 June to 15 December at

886 Poilão Island, at three habitats (OS - 'open sand', FB - 'forest border', F - 'forest'); e, f. bi-

887 weekly proportion of green turtle nesting distribution at Poilão. 

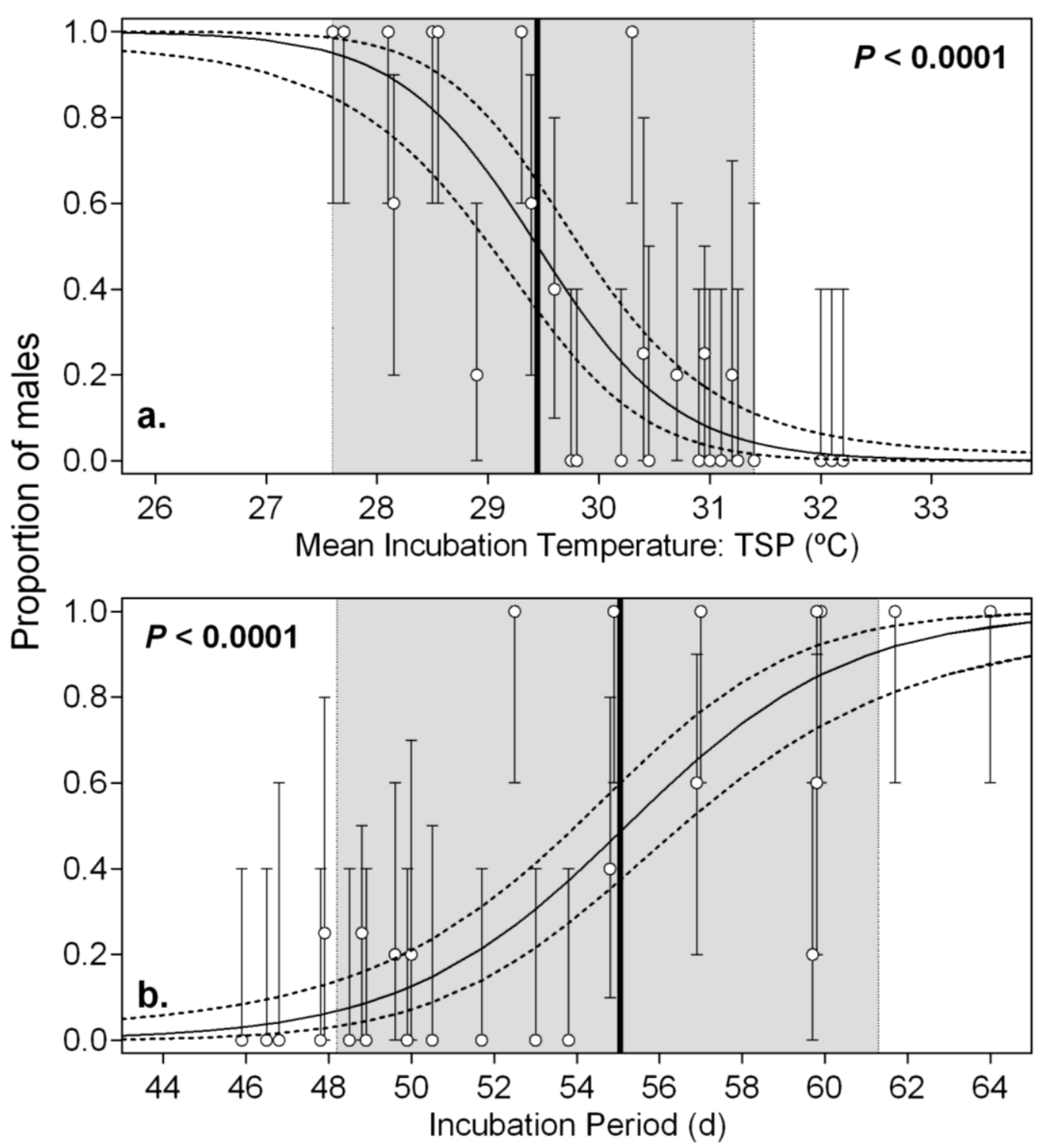

889

890

891

892

893

894

895

896

897

Figure 3. Logistic function (solid curve) and $95 \%$ confidence intervals ( $\mathrm{Cl}$, dashed curves) showing expected proportion of green turtle male hatchlings, as a function of a. thermosensitive period (TSP) mean incubation temperatures, and $\mathbf{b}$. incubation duration, at Poilão Island, Guinea-Bissau. Open circles and 95\% Cl error bars show the proportion of males found in natural nests $(n=27)$, with a mean sample size of $4.9 \pm 0.4$ SD hatchlings per nest. Shaded areas show: limits of transitional range of temperatures (TRT: $27.6-31.4$ ${ }^{\circ}$ C) in a., and corresponding limits of incubation periods (48.1 -61.3 days, $y=-3.4644 x+$ $\left.156.92, r^{2}=0.87\right)$ in $\mathbf{b}$. Straight solid line indicates the pivotal temperature $(29.4 \stackrel{\circ}{\circ})$ in $\mathbf{a}$., and incubation length equivalent (55.1 days) in $\mathbf{b}$. 
2013

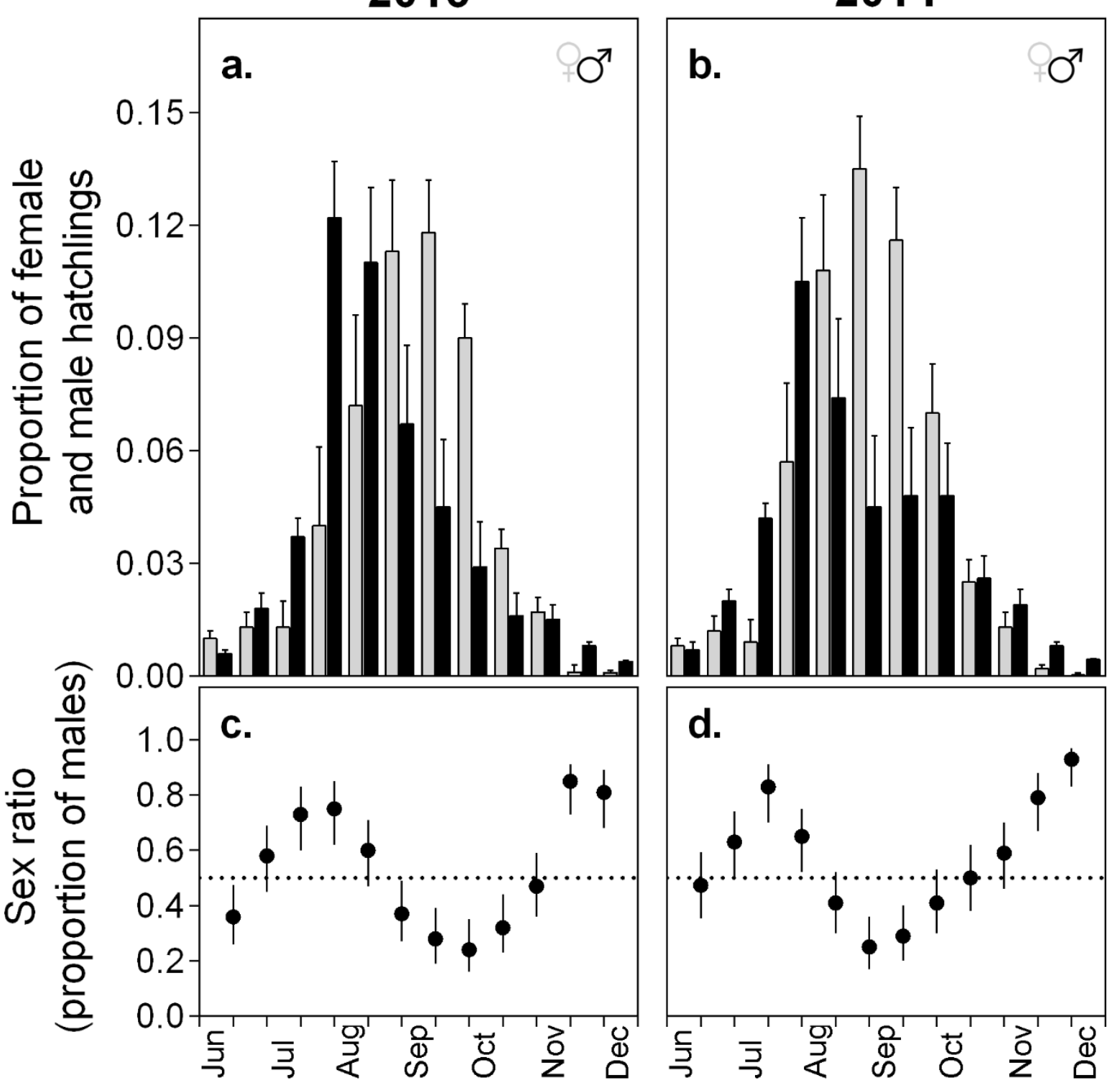

900

Figure 4a, b. Bi-weekly proportion of female (light grey) and of male (dark grey) green turtle

902 hatchlings predicted to have been produced in Poilão, with error bar showing upper 95\%

903 confidence interval $(\mathrm{Cl})$; c.d. estimated mean sex ratio, with $95 \% \mathrm{Cl}$, throughout the nesting 904 season in 20132014. 


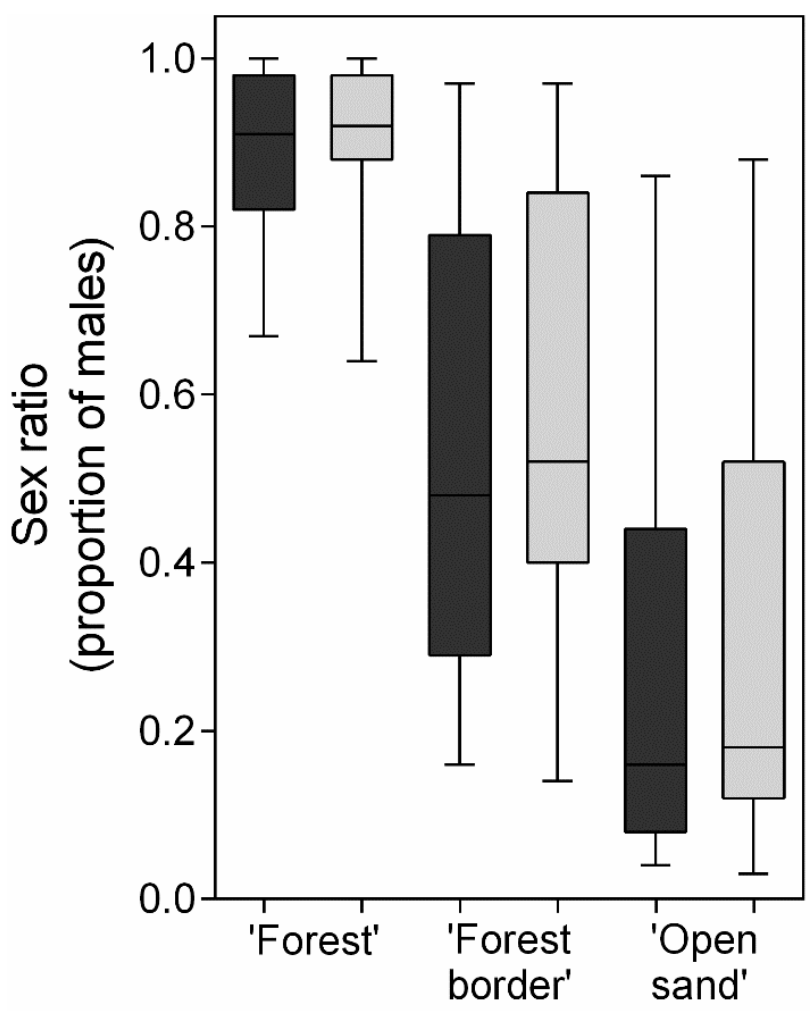

907

908 Figure 5. Estimated mean sex ratios (proportion of males) of green turtle hatchlings in each 909 of three habitats: 'Forest', 'Forest border' and 'Open sand', at Poilão Island, Guinea-Bissau, 910 for 2013 (dark grey) and 2014 (light grey). Boxes show median, upper and lower quartile, 911 and whiskers show highest and lowest observation. 


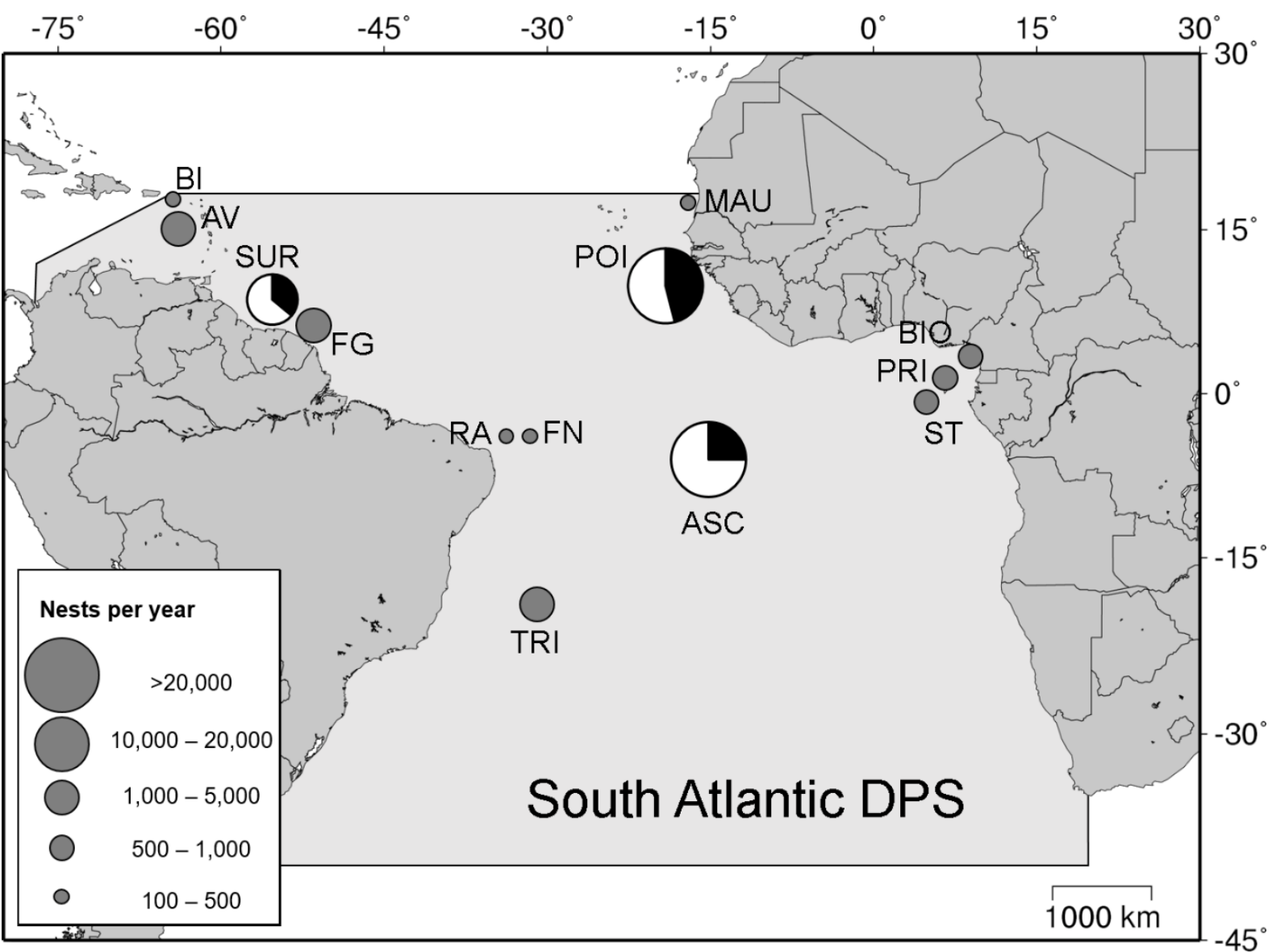

914 Figure 6. Limits of green turtle South Atlantic distinct population segment (DPS), showing rookeries with 100 or more nests. Pie charts indicate primary sex ratio (females: white, males: black), estimated for the three main nesting sites: Suriname (SUR, Godfrey et al. 1996, Seminoff et al. 2015), Ascension Island, UK (ASC, Godley et al. 2002, Weber et al. 2014), and Poilão Island, Guinea-Bissau (POI, this study, Catry et al. 2009). Other rookeries represented by grey circles do not have estimates of primary sex ratios: Buck Island, UK $(\mathrm{BI}$, Seminoff et al. 2015), Aves Island, Venezuela (AV, Garcia Cruz et al. 2015), Yalimapo, French Guiana (FG, Chambault et al. 2016.), Rocas Atol, Brazil (RA, Bellini et al 2013), Fernando de Noronha, Brazil (FN, Bellini, Centro Tamar, pers. comm.), Trindade Island, Brazil (TRI, Almeida et al. 2011), Mauritania (MAU, Fretey pers. comm.), Bioko Island,

924 Equatorial Guinea (BIO, Honarvar et al 2016), and Sao Tome (ST, ATM/MARAPA 2016) and 925 Principe (PRI, Principe Trust Foundation pers. comm.), Sao Tome and Principe (Map created using www.seaturtle.org/maptool). 
Table S1. Chi-square statistics testing if the distribution of green turtle nests at Poilão Island, Guinea-Bissau, along three habitats: 'open sand', years.

\begin{tabular}{|c|c|c|c|c|c|c|c|c|c|}
\hline \multirow{2}{*}{$\begin{array}{c}\text { Beach section } \\
\text { (number / name) }\end{array}$} & \multicolumn{3}{|c|}{$2013(n=3)$} & \multicolumn{3}{|c|}{$2014(n=6)$} & \multicolumn{3}{|c|}{2013 vs. 2014 (n=2) } \\
\hline & chi-square & df & $P$ & chi-square & df & $P$ & chi-square & df & $P$ \\
\hline 1/ Far & 2.78 & 2 & 0.25 & 13.39 & 10 & 0.20 & 1.24 & 2 & 0.54 \\
\hline $2 / \mathrm{AO}$ & 2.33 & 2 & 0.38 & 14.05 & 10 & 0.17 & 0.83 & 2 & 0.66 \\
\hline $3 / \mathrm{AE}$ & 0.68 & 2 & 0.83 & 9.30 & 10 & 0.50 & 0.75 & 2 & 0.72 \\
\hline 4 / Cab & 2.40 & 2 & 0.30 & 7.05 & 10 & 0.72 & 1.53 & 2 & 0.49 \\
\hline
\end{tabular}


934 Table S2. Tukey HSD test - differences in mean incubation temperature during the middle

935 third at four beach sections (see Fig.1b) and three habitats: 'open sand' from $\geq 1 \mathrm{~m}$ of

936 vegetation or tree canopy to high tide line, 'forest border from $0-1 \mathrm{~m}$ of vegetation or tree

937 canopy,' and 'forest', under vegetation or tree canopy. 'diff' is the difference in mean

938 temperatures between beach sections, 'Iwr' and 'upr' are the low and upper 95\% confidence

939 intervals, and $P$ gives the significant level after adjustment for the multiple comparisons.

\begin{tabular}{|c|c|c|c|c|c|}
\hline $\begin{array}{l}\text { Beach } \\
\text { section }\end{array}$ & Habitat & diff & Iwr & upr & $P$ \\
\hline 1 vs. 2 & & 0.32 & -0.46 & 1.10 & 0.97 \\
\hline 1 vs. 3 & & 1.51 & 0.82 & 2.20 & $<0.001$ \\
\hline 1 vs. 4 & & 1.13 & 0.41 & 1.86 & $<0.001$ \\
\hline 2 vs. 3 & & 1.20 & 0.50 & 1.89 & $<0.001$ \\
\hline 2 vs. 4 & & 0.82 & 0.09 & 1.55 & $<0.01$ \\
\hline 3 vs. 4 & & -0.38 & -1.01 & 0.26 & 0.69 \\
\hline 1 vs. 2 & & 0.40 & -0.63 & 1.43 & 0.98 \\
\hline 1 vs. 3 & & 0.88 & -0.33 & 2.09 & 0.39 \\
\hline 1 vs. 4 & & 0.08 & -1.31 & 1.48 & 1.00 \\
\hline 2 vs. 3 & & 0.48 & -0.55 & 1.51 & 0.92 \\
\hline 2 vs. 4 & & -0.32 & -1.56 & 0.92 & 1.00 \\
\hline 3 vs. 4 & & -0.80 & -2.19 & 0.60 & 0.74 \\
\hline 1 vs. 2 & & -0.12 & -2.03 & 1.79 & 1.00 \\
\hline 1 vs. 3 & & 0.01 & -1.90 & 1.91 & 1.00 \\
\hline 1 vs. 4 & & 0.06 & -1.42 & 1.54 & 1.00 \\
\hline 2 vs. 3 & & 0.13 & -1.78 & 2.03 & 1.00 \\
\hline 2 vs. 4 & & 0.18 & -1.30 & 1.66 & 1.00 \\
\hline 3 vs. 4 & & 0.06 & -1.42 & 1.54 & 1.00 \\
\hline
\end{tabular}


Table S3. Habitat and beach section, incubation period ti hatching (IP), mean incubation temperatures during both the middle third (MT) of incubation and the thermo-sensitive period (TSP), and difference in days of between start and end of the MT of incubation and estimated TSP (using embryogrowth v.6.4 R package, Girondot and Kaska 2014), of 27 green turtle nests, incubated under natural conditions at Poilão Island, in the methods section. For beach section definitions see Fig.1b.

\begin{tabular}{|c|c|c|c|c|c|c|c|c|c|c|c|c|}
\hline \multirow{2}{*}{ Nest ID } & \multirow{2}{*}{ Habitat } & \multirow{2}{*}{$\begin{array}{l}\text { Beach } \\
\text { section }\end{array}$} & \multirow{2}{*}{ IP } & \multicolumn{2}{|c|}{ Mean temperature ${ }^{\circ} \mathrm{C}$} & \multicolumn{2}{|c|}{$\Delta$ TSP and MT (days) } & \multicolumn{2}{|c|}{ Sexed hatchlings } & \multicolumn{3}{|c|}{ Proportion of males } \\
\hline & & & & MT & TSP & Start & End & total & males & mean & low $95 \% \mathrm{Cl}$ & up $95 \% \mathrm{Cl}$ \\
\hline N54 & forest & 3 & 61.7 & 27.6 & 27.6 & 1 & 3 & 5 & 5 & 1.0 & 0.6 & 1.0 \\
\hline N66 & forest & 3 & 61.4 & 27.5 & 27.7 & 2 & 4 & 5 & 5 & 1.0 & 0.6 & 1.0 \\
\hline N78 & forest & 4 & 59.8 & 27.8 & 28.1 & 2 & 4 & 5 & 3 & 0.6 & 0.2 & 0.9 \\
\hline N77 & forest & 2 & 59.8 & 27.8 & 28.1 & 2 & 4 & 5 & 5 & 1.0 & 0.6 & 1.0 \\
\hline N53 & forest & 1 & 59.7 & 28.3 & 28.5 & 2 & 3 & 5 & 5 & 1.0 & 0.6 & 1.0 \\
\hline N70 & forest & 4 & 56.9 & 28.1 & 28.5 & 2 & 5 & 5 & 5 & 1.0 & 0.6 & 1.0 \\
\hline N51 & forest & 4 & 59.7 & 28.8 & 28.9 & 1 & 2 & 5 & 1 & 0.2 & 0.0 & 0.6 \\
\hline N79 & forest & 4 & 54.8 & 28.9 & 29.3 & 3 & 4 & 5 & 5 & 1.0 & 0.6 & 1.0 \\
\hline N40 & forest border & 4 & 56.9 & 29.4 & 29.4 & 1 & 2 & 5 & 3 & 0.6 & 0.2 & 0.9 \\
\hline N39 & forest border & 2 & 54.8 & 29.4 & 29.6 & 2 & 4 & 5 & 2 & 0.4 & 0.1 & 0.8 \\
\hline N76 & forest border & 2 & 53.8 & 29.7 & 29.8 & 1 & 2 & 5 & 0 & 0.0 & 0.0 & 0.4 \\
\hline N81 & forest border & 1 & 51.7 & 29.3 & 29.8 & 3 & 5 & 5 & 0 & 0.0 & 0.0 & 0.4 \\
\hline N73 & forest border & 1 & 48.9 & 29.7 & 30.2 & 3 & 5 & 5 & 0 & 0.0 & 0.0 & 0.4 \\
\hline N62 & open sand & 1 & 52.5 & 30.1 & 30.3 & 1 & 2 & 5 & 5 & 1.0 & 0.6 & 1.0 \\
\hline N63 & open sand & 1 & 50.5 & 30.1 & 30.4 & 2 & 4 & 4 & 0 & 0.0 & 0.0 & 0.5 \\
\hline N84 & forest border & 3 & 47.8 & 30.0 & 30.4 & 3 & 5 & 4 & 1 & 0.3 & 0.0 & 0.8 \\
\hline N57 & open sand & 2 & 49.6 & 30.5 & 30.7 & 2 & 3 & 5 & 1 & 0.2 & 0.0 & 0.6 \\
\hline N44 & open sand & 1 & 48.8 & 30.6 & 30.9 & 3 & 5 & 4 & 1 & 0.3 & 0.0 & 0.5 \\
\hline N72 & open sand & 2 & 49.9 & 30.8 & 30.9 & 1 & 2 & 5 & 0 & 0.0 & 0.0 & 0.4 \\
\hline N71 & open sand & 4 & 48.8 & 30.8 & 31.0 & 1 & 2 & 5 & 0 & 0.0 & 0.0 & 0.4 \\
\hline N32 & open sand & 4 & 53.0 & 30.9 & 31.1 & 2 & 2 & 5 & 0 & 0.0 & 0.0 & 0.4 \\
\hline N60 & open sand & 4 & 46.5 & 30.8 & 31.2 & 2 & 4 & 5 & 0 & 0.0 & 0.0 & 0.4 \\
\hline N37 & open sand & 3 & 50.0 & 30.8 & 31.2 & 3 & 4 & 5 & 1 & 0.2 & 0.0 & 0.7 \\
\hline N82 & open sand & 2 & 46.8 & 30.9 & 31.4 & 2 & 3 & 4 & 0 & 0.0 & 0.0 & 0.6 \\
\hline N68 & open sand & 2 & 45.9 & 31.8 & 32.0 & 2 & 2 & 5 & 0 & 0.0 & 0.0 & 0.4 \\
\hline N34 & open sand & 2 & 48.5 & 31.6 & 32.1 & 3 & 3 & 5 & 0 & 0.0 & 0.0 & 0.4 \\
\hline N47 & open sand & 2 & 47.8 & 32.2 & 32.2 & 1 & 2 & 5 & 0 & 0.0 & 0.0 & 0.4 \\
\hline
\end{tabular}



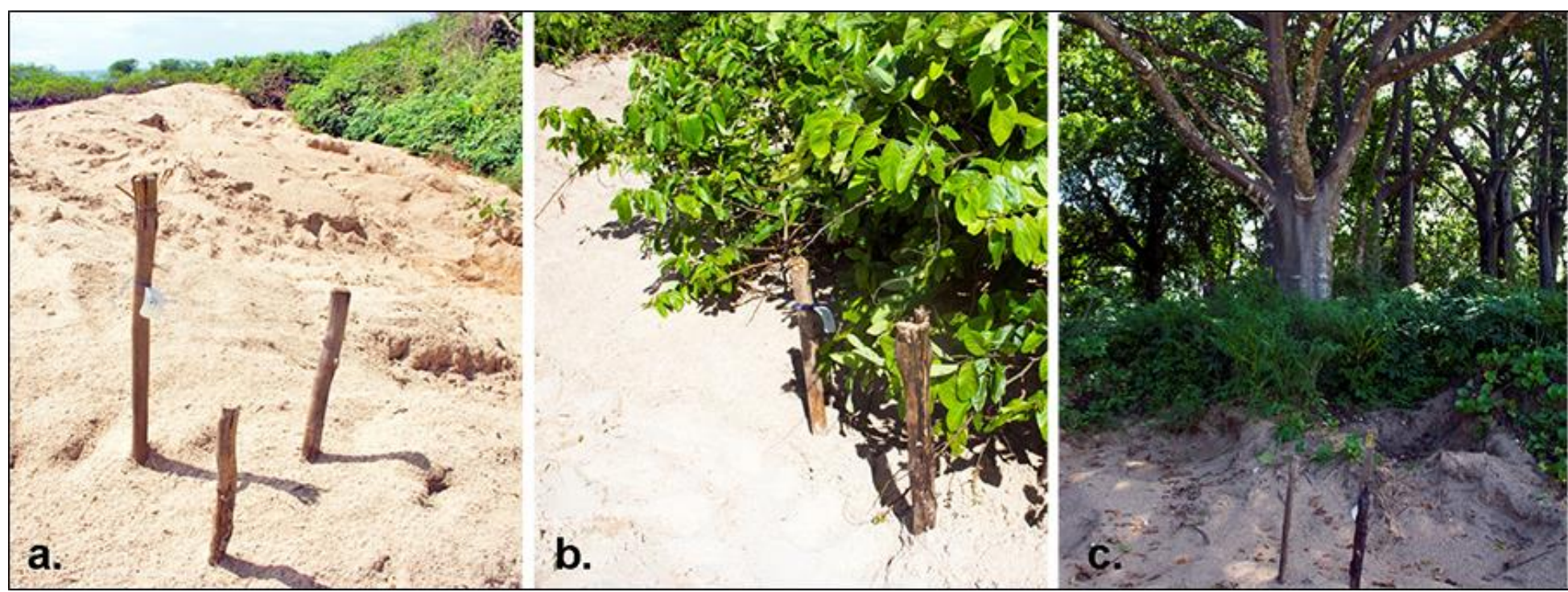

Figure S1. Nesting habitats utilized by green turtles at Poilão Island, Guinea-Bissau, according to vegetation cover: a. 'open sand' habitat, from

$>1 \mathrm{~m}$ of the vegetation to high tide line, completley exposed to the sun; $\mathbf{b}$. 'forest border', comprised between 0 - $1 \mathrm{~m}$ of the vegetation line, with

951 surround clucth location.

952 


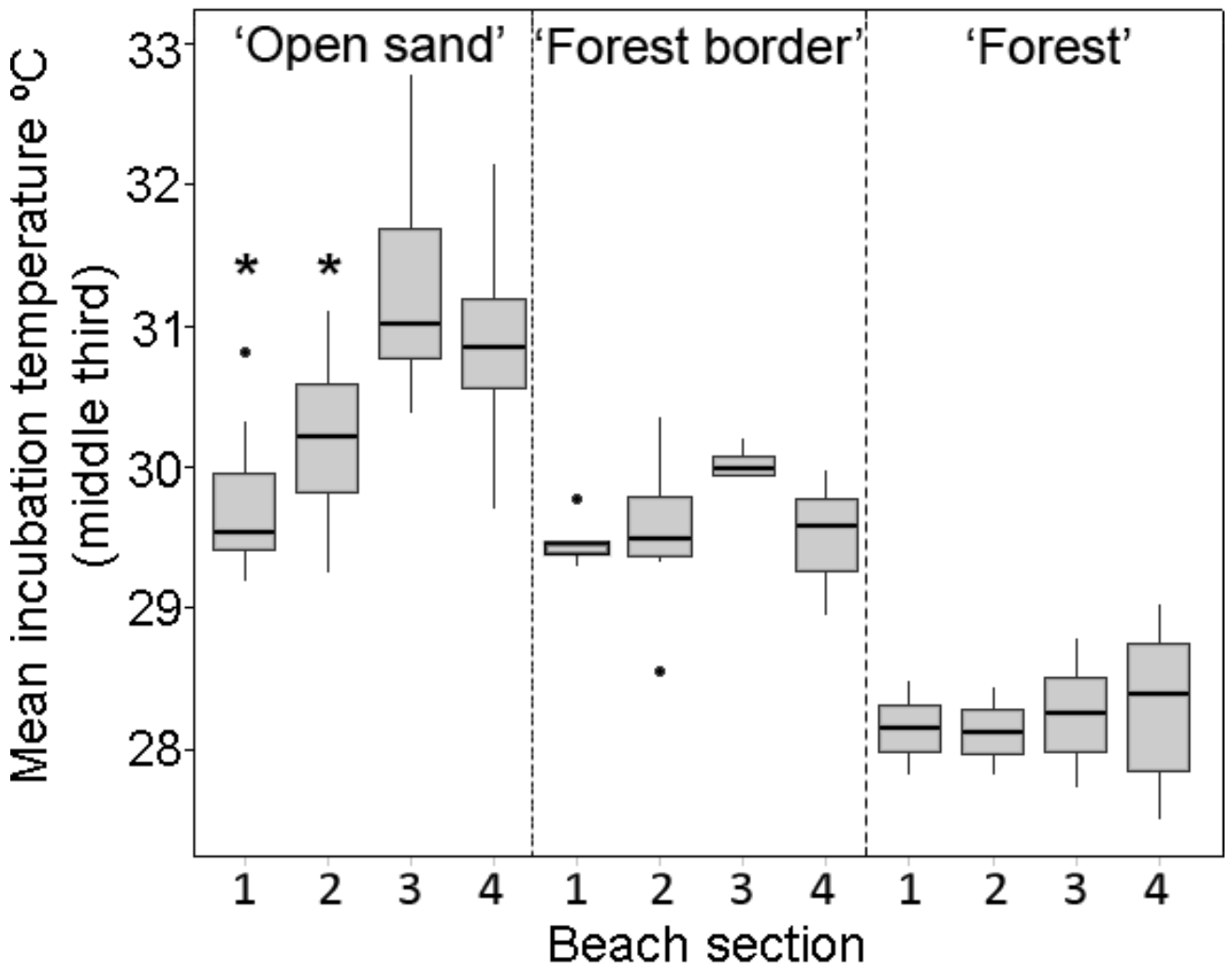

955

956

957 Figure S2. Middle third mean incubation temperatures of green turtle nests in three different 958 habitats and four beach sections, at Poilão Island, Guinea-Bissau. Asterisks indicate 959 significant differences within same habitat. For beach sections see Fig.1b. Habitat definitions 960 can be found in the methods section. 


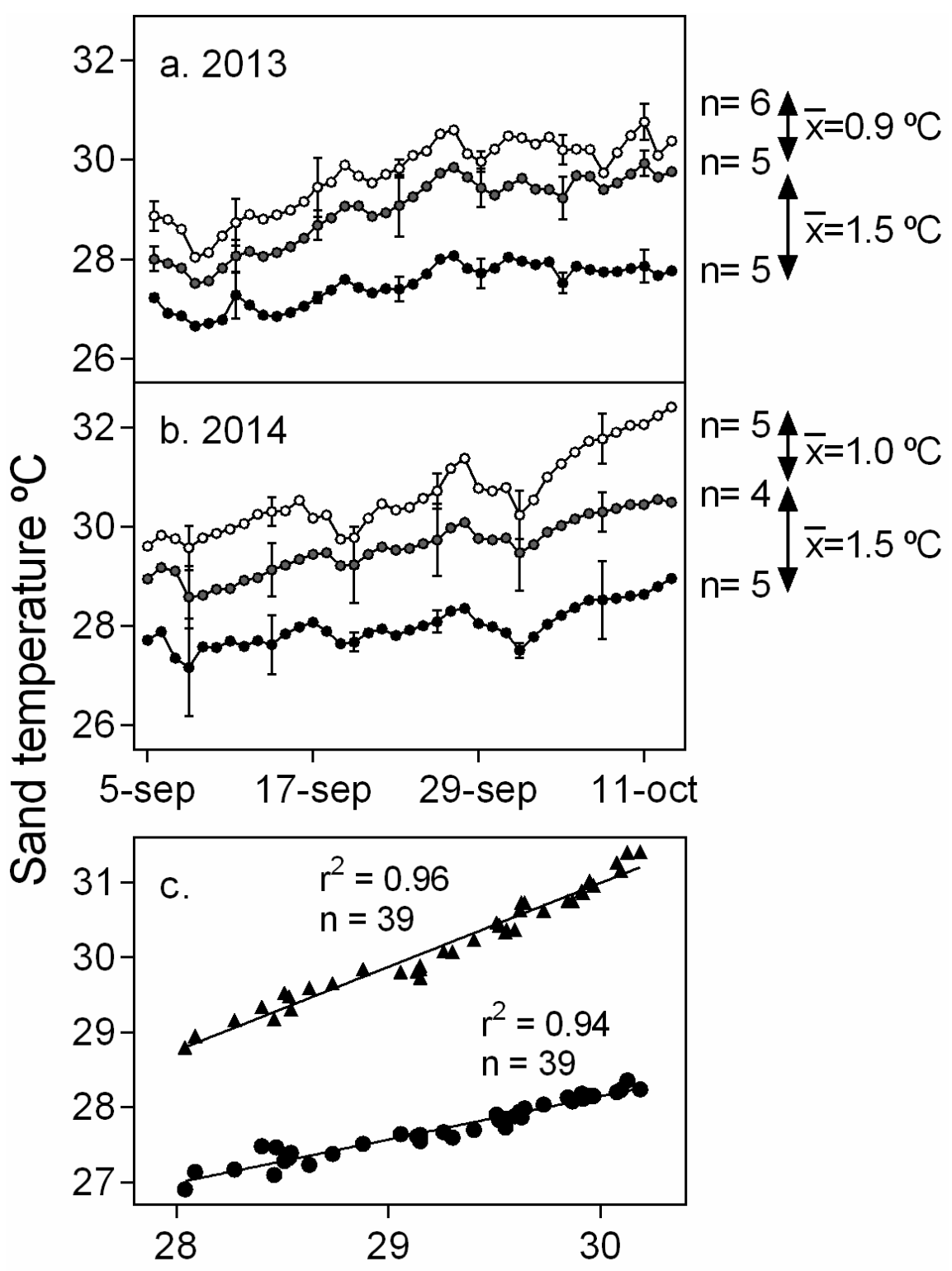

Figure S3. Sand temperature at Poilão Island, a green turtle nesting beach, in three habitats: 'open sand' (open circles), from > $1 \mathrm{~m}$ of vegetation line to high tide line, 'forest border' (grey circles), 0-1m of vegetation line, and 'forest' (black circles), under vegetation, for 2013 (a) and 2014 (b). ' $n$ ' is the number of data loggers recording temperature at each

969 habitat ( $0.3^{\circ} \mathrm{C}$ resolution), and $\bar{x}$ denotes mean difference between habitats. c. Linear

970 regressions between mean sand temperatures at the 'forest border' and the 'open sand'

971 (triangles), and the 'forest' (circles) habitats. 


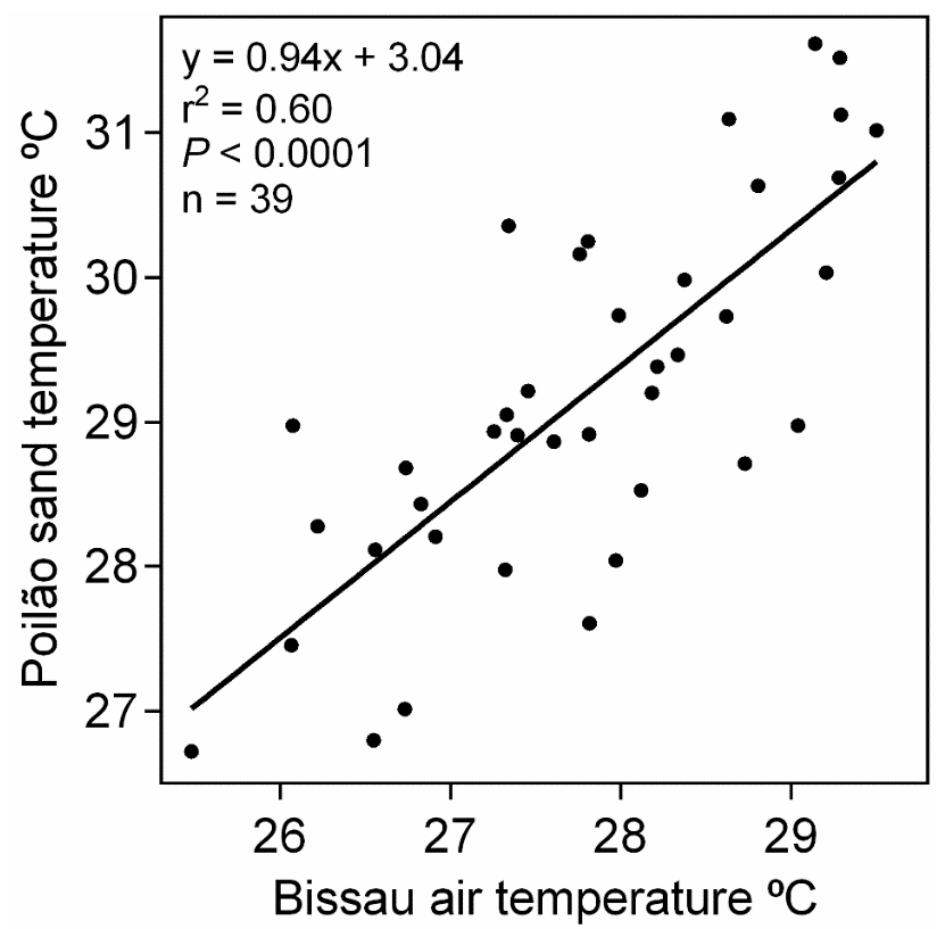

973

974

975 Figure S4. Linear regression between mean bi-weekly sand temperatures at Poilão

976 (reference data loggers) and air temperatures in Bissau (http://cdo.ncdc.noaa.gov/CDO/cdo). 